\title{
Nalcn Is a "Leak" Sodium Channel That Regulates Excitability of Brainstem Chemosensory Neurons and Breathing
}

\author{
Yingtang Shi, Chikara Abe, Benjamin B. Holloway, @Shaofang Shu, Natasha N. Kumar, Janelle L. Weaver, Josh Sen, \\ Edward Perez-Reyes, $\bigcirc$ Ruth L. Stornetta, $\odot$ Patrice G. Guyenet and $\odot$ Douglas A. Bayliss \\ Department of Pharmacology, University of Virginia, Charlottesville, Virginia 22908
}

The activity of background potassium and sodium channels determines neuronal excitability, but physiological roles for "leak" $\mathrm{Na}^{+}$ channels in specific mammalian neurons have not been established. Here, we show that a leak $\mathrm{Na}^{+}$channel, Nalcn, is expressed in the $\mathrm{CO}_{2} / \mathrm{H}^{+}$-sensitive neurons of the mouse retrotrapezoid nucleus (RTN) that regulate breathing. In RTN neurons, Nalcn expression correlated with higher action potential discharge over a more alkalized range of activity; shRNA-mediated depletion of Nalcn hyperpolarized RTN neurons, and reduced leak $\mathrm{Na}^{+}$current and firing rate. Nalcn depletion also decreased RTN neuron activation by the neuropeptide, substance $\mathrm{P}$, without affecting $\mathrm{pH}$-sensitive background $\mathrm{K}^{+}$currents or activation by a cotransmitter, serotonin. In vivo, RTN-specific knockdown of Nalcn reduced $\mathrm{CO}_{2}$-evoked neuronal activation and breathing; hypoxic hyperventilation was unchanged. Thus, Nalcn regulates RTN neuronal excitability and stimulation by $\mathrm{CO}_{2}$, independent of direct $\mathrm{pH}$ sensing, potentially contributing to respiratory effects of Nalcn mutations; transmitter modulation of Nalcn may underlie state-dependent changes in breathing and respiratory chemosensitivity.

Key words: Phox2b; respiratory chemoreceptors; retrotrapezoid nucleus; substance P; ventilation

\section{Significance Statement}

Breathing is an essential, enduring rhythmic motor activity orchestrated by dedicated brainstem circuits that require tonic excitatory drive for their persistent function. A major source of drive is from a group of $\mathrm{CO}_{2} / \mathrm{H}^{+}$-sensitive neurons in the retrotrapezoid nucleus (RTN), whose ongoing activity is critical for breathing. The ionic mechanisms that support spontaneous activity of RTN neurons are unknown. We show here that Nalcn, a unique channel that generates "leak" sodium currents, regulates excitability and neuromodulation of RTN neurons and $\mathrm{CO}_{2}$-stimulated breathing. Thus, this work defines a specific function for this enigmatic channel in an important physiological context.

\section{Introduction}

Neural control of respiration involves a brainstem central pattern generator (CPG) that regulates lung ventilation and gas exchange (Feldman et al., 2013; Smith et al., 2013; Guyenet and Bayliss, 2015). Persistent rhythmic activity of the respiratory CPG requires tonic excitatory input, which is modulated by respiratory

\footnotetext{
Received April 1, 2016; revised May 19, 2016; accepted June 15, 2016.

Author contributions:Y.S., E.P.-R., P.G.G., and D.A.B. designed research;Y.S., C.A., B.B.H., S.S., N.N.K., J.L.W., J.S., E.P.-R., R.L.S., and P.G.G. performed research; E.P.-R. contributed unpublished reagents/analytic tools; Y.S., S.S., N.N.K., J.L.W., J.S., R.L.S., and D.A.B. analyzed data; Y.S., P.G.G., and D.A.B. wrote the paper.

This work was supported by National Institutes of Health Grants NS080061 to E.P.-R., HL074011 to P.G.G., and HL108609 to D.A.B.

The authors declare no competing financial interests.

Correspondence should be addressed to Dr. Douglas A. Bayliss, Department of Pharmacology, University of Virginia Health System, 5009A Jordan Hall, P0 Box 800735, 1340 Jefferson Park Avenue, Charlottesville, VA 229080735. E-mail: bayliss@virginia.edu.

DOI:10.1523/JNEUROSCI.1096-16.2016

Copyright $\odot 2016$ the authors $\quad 0270-6474 / 16 / 368174-14 \$ 15.00 / 0$
}

feedback and information regarding brain state (Feldman et al., 2013; Smith et al., 2013; Guyenet and Bayliss, 2015).

The tonically active, Phox2b-expressing glutamatergic neurons of the retrotrapezoid nucleus (RTN) are a principal site responsible for integrating feedback/feedforward information for transmission to the respiratory CPG (Feldman et al., 2013; Smith et al., 2013; Guyenet and Bayliss, 2015). Optogenetic activation of RTN neurons stimulates respiratory output (Abbott et al., 2009), whereas optogenetic/chemogenetic inhibition of RTN neurons can abruptly stop breathing (Marina et al., 2010; Basting et al., 2015). In addition, tonic RTN neuron activity is influenced by changes in blood gases and brain $\mathrm{pH}$ (i.e., chemosensitivity) (Mulkey et al., 2004; Gourine et al., 2010; Wang et al., 2013a, b; Guyenet and Bayliss, 2015; Kumar et al., 2015), with effects on respiration that are dependent on sleep-wake state (Burke et al., 2015). Patients with congenital central hypoventilation syndrome have mutations in Phox $2 \mathrm{~b}$ and suffer from blunted 
respiratory chemosensitivity and potentially fatal episodes of hypoventilation during sleep (Amiel et al., 2003; Weese-Mayer et al., 2010); moreover, a mouse genetic model incorporating a common disease-causing polyalanine expansion mutation in Phox $2 \mathrm{~b}\left(\mathrm{Phox} 2 \mathrm{~b}^{27 \mathrm{Ala} /+}\right.$ ) phenocopies the congenital central hypoventilation syndrome breathing disturbances, and RTN neurons specifically fail to develop in those mice (Dubreuil et al., 2008; Ramanantsoa et al., 2011).

A dynamic balance of inward and outward current regulates spontaneous discharge in tonically firing neurons. In RTN neurons, background "leak" $\mathrm{K}^{+}$channels provide a hyperpolarizing current that is regulated by $\mathrm{pH}$ to mediate neuronal chemosensitivity (Mulkey et al., 2004; Wang et al., 2013a, b; Kumar et al., 2015). However, the nature of the countervailing background depolarizing current has not been established. In various spontaneously firing neurons, background $\mathrm{Na}^{+}$currents are mediated by persistent, resurgent, or "window" activity from voltage-gated $\mathrm{Na}_{\mathrm{V}}$ channels (Raman and Bean, 1997; Taddese and Bean, 2002; Bean, 2007; Koizumi and Smith, 2008; Khaliq and Bean, 2010; Smith et al., 2013), but in some cases TTX-insensitive, voltageindependent background currents have also been described (Raman et al., 2000; Eggermann et al., 2003; Jackson et al., 2004). A potential conduit for such background inward current is Nalcn ( $\mathrm{Na}^{+}$leak channel, nonselective) (Lu et al., 2007, 2009; Ren, 2011; Cochet-Bissuel et al., 2014). Although structurally related to the $\mathrm{Na}_{\mathrm{V}}$ family of voltage-dependent $\mathrm{Na}^{+}$-selective channels, Nalcn is TTX resistant and forms a voltage-independent, nonselective cation channel that generates a "leak" inward current, carried primarily by $\mathrm{Na}^{+}$ions under physiological conditions (Lu et al., 2007, 2009; Ren, 2011; Cochet-Bissuel et al., 2014); Nalcn current can be further enhanced by various neuromodulators (Lu et al., 2009; Ren, 2011; Cochet-Bissuel et al., 2014). Notably, global genetic deletion of Nalcn leads to disrupted respiration and early postnatal death in mice (Lu et al., 2007), and patients with Nalcn mutations present with respiratory dysfunction, among other disorders (Al-Sayed et al., 2013; Köroğlu et al., 2013; Cochet-Bissuel et al., 2014; Chong et al., 2015; Gal et al., 2016). A contribution of Nalcn to endogenous currents in respiratory neurons has not been demonstrated.

Here, we used shRNA-mediated knockdown to demonstrate that Nalcn contributes to background $\mathrm{Na}^{+}$current and excitability in $\mathrm{pH}$-sensitive $\mathrm{RTN}$ neurons, and is required for activation of RTN neurons by the neuropeptide substance P (SP). Further, we show that RTN-selective depletion of Nalcn in vivo constrains $\mathrm{CO}_{2}$-induced activation of RTN neurons and blunts respiratory responses to $\mathrm{CO}_{2}$. Thus, these data define a specific physiological role for Nalcn in control of breathing by RTN respiratory integrator neurons.

\section{Materials and Methods}

Experiments were performed on mice of either sex, following procedures adhering to National Institutes of Health Animal Care and Use Guidelines and approved by the Animal Care and Use Committee of the University of Virginia. These studies used a Phox $2 b::$ GFP BAC transgenic mouse line (Jx99), developed by the GENSAT project and characterized previously (Lazarenko et al., 2009).

Single-cell molecular biology of RTN neurons. Individual GFP-labeled RTN neurons were harvested for RT-PCR either after acute dissociation or following patch-clamp recording in brainstem slices or slice cultures from neonatal Phox $2 b:: G F P$ mice (P7-P11), essentially as described previously (Lazarenko et al., 2010; Wang et al., 2013a, b; Kumar et al., 2015). For dissociated RTN neurons, single fluorescent cells were identified in the recording chamber of a fluorescence microscope (Zeiss Axioimager FS) and aspirated into a glass capillary; for RTN neurons functionally
Table 1. Primer sequences for single-cell RT-PCR and qRT-PCR

\begin{tabular}{lll}
\hline Primer & Sequence & Amplicon \\
& (bp)
\end{tabular}

GAPDH (glyceraldehyde 3-phosphate dehydrogenase; NCBI: GU214026.1) Outside, forward Outside, reverse Nested, forward ${ }^{a}$ Nested, reverse $e^{a}$

VGlut2 (vesicular glutamate transporter 2; NCBI: AF324864.1)

Outside, forward

Outside, reverse

Nested, forward ${ }^{a}$

Nested, reverse $e^{a}$

Phox2b (paired-like homeobox 2b; NCBI: NM 008888.3)

Outside, forward

Outside, reverse

Nested, forward

Nested, reverse

GAD1 (glutamate decarboxylase 1; NCBI:NM_008077.4)

Outside, forward

Outside, reverse

Nested, forward

Nested, reverse

Nalcn (sodium leak channel, nonselective; NCBI: NM_177393.4)

Outside, forward

Outside, reverse

Nested, forward

Nested, reverse

Quantitative, forward

Quantitative, reverse

NK1R (tachykinin receptor 1; NCBI: NM_009313.5)

Outside, forward

Outside, reverse

Nested, forward

Nested, reverse

Quantitative, forward

Quantitative, reverse

NK2R (tachykinin receptor 2; NCBI: NM_009314.4)

Outside, forward

Outside, reverse

Nested, forward

Nested, reverse

NK3R (tachykinin receptor 3; NCBI: NM 021382.6)

Outside, forward

Outside, reverse

Nested, forward ${ }^{a}$

Nested, reverse ${ }^{a}$

AAATGGTGAAGGTCGGTGTGAACG

AGTGATGGCATGGACTGTGGTCAT GCAAATTCAACGGCACAGTCAAGG TCTCGTGGTTCACACCCATCACAA

542

255

TCTCTGGTCACACCCATCACAA

CTGCTTCTGGTTGTTGGCTACTCT

ATCTCGGTCCTTATAGGTGTACGC

САTCTCCTTCTTGGTGCTTGCAGT

ACAGCGTGCCAACGCCATTTGAAA

543

131

CAGTGGCTTCCAGTATAACCCGAT

AGCGAAGACCCTCTCCAACTCTTT

TACGCGGCAGTTCCATACAAACTC

TCTTTGAGCTGCGCGCTTGTGAAG

238

104

ACAACCTTTGGCTGCATGTGGATG

331

AATCCCACGGTGCCCTTTGCTTTC

AGTCACCTGGAACCCTC

GCTTGTCTGGCTGGAA

128

ATGCTCAAAAGAAAGCAGAGTTCCA AATCGGAAATAAATCCTGAAAGCCC ATACTCTGGATTAATAAGCCA

ATAGGAGCTATCACCCTTGACAATT

TAATGAGATAGGCACGAGTA

TGATGAAGTAGAAGTAGGAGC

479

219

122

ATCGTGGTGACTTCCGTGGTG

449

GTCCTGTTGGGATGTTCTGGC

CCCACAAGAGAATGAGGAC

CCCAGATGACAAAGATGAC

СCTGCCCTACATCAACCCA

TGAAGCCCAGACGGAACCT

291

143

GCCACCTTCAACTTCATCTA

GCCTTCACAAACTTCTTCTT

TCATCTACTTCCTGCCTCTA

GCCTTCACAAACTTCTTCTT

494

142

AAAACTGGACGGACGGGAC

CACTGCACATAGCAAAGGG

AACTTCTTTCCCATCACAGCG

GCCAAAATCCAAATACTTCCG

${ }^{a}$ Same primers also used for qPCR.

characterized by patch-clamp recording, cell contents were aspirated after obtaining whole-cell access. Analysis of multiple genes in single-cell assays used either multiplex nested single-cell RT-PCR (sc-PCR) or multiplex quantitative sc-PCR (sc-qPCR). Intron-spanning, nested primer sets across splice sites for each gene of interest were used in sc-PCRs (for sc-PCR and sc-qPCR primer information, see Table 1). All primer sets were independently validated, and no-template negative controls were included for each reaction. For sc-qPCR, we followed published procedures (Liss, 2002). In brief, we used an iCycler iQ (Bio-Rad) and Bio-Rad iQ SYBR Green Supermix in a $25 \mu \mathrm{l}$ reaction volume. Specificity of the 
primers was assessed by generating a melting curve of the PCR product and standard curve; PCR efficiencies were determined for all primer pairs used in sc- $\mathrm{PPCR}$ assays $(92 \%-100 \%)$. The protocol entailed: denaturation $\left(95^{\circ} \mathrm{C}, 10 \mathrm{~min}\right)$, amplification and quantification $\left(42\right.$ cycles: $95^{\circ} \mathrm{C}$, $20 \mathrm{~s} ; 60^{\circ} \mathrm{C}, 20 \mathrm{~s} ; 72^{\circ} \mathrm{C}, 20 \mathrm{~s}$ ), and melt curve analysis (ramp from $55^{\circ} \mathrm{C}$ to $95^{\circ} \mathrm{C}, 0.5^{\circ} \mathrm{C}$ increments for $2 \mathrm{~s}$ ). Cycle threshold $\left(\mathrm{C}_{\mathrm{t}}\right)$ levels were rescaled by their average and transformed into relative quantities using the amplification efficiency, as described previously (Pfaffl, 2001). The $\mathrm{C}_{t}$ values of test genes were normalized to GAPDH, an internal reference gene.

Virus production. We used two different viral transduction systems to infect RTN neurons in vitro and in vivo: adeno-associated virus 2 (AAV2) for slice cultures and lentivirus for in vivo studies. For AAV2 production, different Nalcn shRNA hairpin sequences were inserted into a selfcomplementary AAV targeting construct downstream of an $\mathrm{H} 1$ promoter; the vector also provided an mCherry reporter driven by a CMV-synapsin promoter (see Fig. 2). To test knockdown efficiency of each shRNA hairpin, HEK293T cells were cotransfected with the viral targeting construct and a rat Nalcn plasmid that shared the shRNA target sequences (Lee et al., 1999). Knockdown efficiency was evaluated by qRT-PCR $(24,48$, and $72 \mathrm{~h}$ after transfection) and the most effective shRNA ( $\sim 70 \%$ knockdown), with its corresponding scrambled control were selected for preparation of high-titer AAV2 virus $\left(1.0 \times 10^{12}\right.$ transduction units (TU)/ml; Vector Core, University of North Carolina, Chapel Hill, NC). The shRNA hairpin sequences used in this study were previously described (Nalcn shRNA: AAGATCGCACAGCCTCTTCAT; scrambled: GCTCAGTACGATCATACTCAC) (Swayne et al., 2010).

For in vivo experiments, a customized lentivirus targeting vector was prepared (see Fig. 5) that used an artificial PRSx8 promoter to drive the same shRNA hairpin sequence, along with mCherry, selectively in Phox2b-expressing RTN neurons (Hwang et al., 2001; Abbott et al., 2009). With this construct, knockdown was also 70\% in HEK293T cells coexpressing Nalcn. Replication-deficient high-titer lentivirus was produced in-house. Briefly, HEK293T cells were transfected with a secondgeneration packaging plasmid (pPAX2) and a pseudotyping envelope plasmid (pMD2.G). The viral supernatant was harvested $48-72 \mathrm{~h}$ later, when transfection efficiency was $\sim 100 \%$ (gauged by mCherry fluorescence). The virus was purified by low-speed centrifugation and syringe filtration (Merck Millipore SLHV033RS) to remove cellular debris, and then concentrated by ultra-centrifugation $\left(30,000 \mathrm{RPM}, 2.5 \mathrm{~h}\right.$, at $4^{\circ} \mathrm{C}$; Beckman SW41 Ti rotor). The pellet was resuspended in DMEM, and the virus was stored at $-80^{\circ} \mathrm{C}$. For titer estimation, we incubated HEK293T cells with a dilution series of virus and counted the number of fluorescent cells $\left(1.0 \times 10^{11} \mathrm{TU} / \mathrm{ml}\right)$.

Organotypic slice culture. Cultured slices were prepared from neonatal Phox2b::GFP mice (P6-P7), as described previously (Qin et al., 2005; Lim et al., 2014). Briefly, pups were anesthetized with ketamine and xylazine (375 mg/kg and $25 \mathrm{mg} / \mathrm{kg}$, i.m.). Brainstems were removed in ice-cold Hank's Balanced Salt Solution, containing the following (in $\mathrm{mm}$ ): 1 kynurenic acid, $1 \mathrm{HEPES}, 20$ glucose, and $10 \mathrm{MgCl}_{2}$. Slices were cut in the coronal plane $(400 \mu \mathrm{m})$ with a microslicer (DSK 1500E; Dosaka) and then transferred onto a Millicell-CM culture inserts $(0.4 \mathrm{~mm}$ pore size; Millipore) containing $1 \mathrm{ml}$ of culture medium (mM) as follows: 30 HEPES, 1 glutamine, 13 D-glucose, $5 \mathrm{NaHCO}_{3}, 1 \mathrm{CaCl}_{2}, 2 \mathrm{MgSO}_{4}$, with $50 \%$ minimal essential medium, $20 \%$ heat-inactivated horse serum, 1 $\mathrm{mg} / \mathrm{ml}$ insulin, and $0.012 \%$ ascorbic acid at pH 7.28 and $320 \mathrm{mOsm}$. Slices were maintained at $35^{\circ} \mathrm{C}$ in a humidified incubator equilibrated with $95 \% \mathrm{O}_{2}$ and $5 \% \mathrm{CO}_{2}$. For viral transduction, $10 \mu \mathrm{l}$ of AAV2 (diluted to $\sim 1 \times 10^{9} \mathrm{TU} / \mathrm{ml}$ ) was pipetted onto the surface of each slice at day 3 after slice preparation; slices were used within 2-4 weeks.

Electrophysiology. Acute slice preparation was essentially as described above, except that $300 \mu \mathrm{m}$ brainstem slices were cut from P7-P11 mice in ice-cold sucrose-substituted solution, containing the following (in $\mathrm{mm}$ ): 260 sucrose, $3 \mathrm{KCl}, 5 \mathrm{MgCl}_{2}, 1 \mathrm{CaCl}_{2}, 1.25 \mathrm{NaH}_{2} \mathrm{PO}_{4}, 26 \mathrm{NaHCO}_{3}, 10$ D-glucose, and 1 kynurenic acid. Slices were incubated for $30 \mathrm{~min}$ at $37^{\circ} \mathrm{C}$ and subsequently at room temperature in normal Ringer's solution containing the following (in mM): $130 \mathrm{NaCl}, 3 \mathrm{KCl}, 2 \mathrm{MgCl}_{2}, 2 \mathrm{CaCl}_{2}, 1.25$ $\mathrm{NaH}_{2} \mathrm{PO}_{4}, 26 \mathrm{NaHCO}_{3}$, and 10 D-glucose. Both cutting and incubation solutions were bubbled with $95 \% \mathrm{O}_{2}$ and $5 \% \mathrm{CO}_{2}$.
Electrophysiological recordings from GFP-labeled neurons in both acute and cultured slices were performed in a recording chamber mounted on a fluorescence microscope (Zeiss Axioimager FS) in HEPES-based perfusate, containing the following (in mM): $140 \mathrm{NaCl}, 3$ $\mathrm{KCl}, 2 \mathrm{MgCl}_{2}, 2 \mathrm{CaCl}_{2}, 10 \mathrm{HEPES}, 10 \mathrm{D}$-glucose; a mixture of blockers was added (10 $\mu \mathrm{M}$ CNQX, $10 \mu \mathrm{M}$ bicuculline, $30 \mu \mathrm{M}$ strychnine) to inhibit fast excitatory (glutamate) and inhibitory transmitters (GABA, glycine). The $\mathrm{pH}$ of the bath solution was adjusted between 7.0 and 8.0 by addition of $\mathrm{HCl}$ or $\mathrm{NaOH}$. For some experiments, we replaced extracellular $\mathrm{Na}^{+}$with equimolar $\mathrm{N}$-methyl D-glucamine $\left(\mathrm{NMDG}^{+}\right)$. Patch electrodes had a DC resistance of 3-6 $\mathrm{M} \Omega$. For cell-attached recordings of firing rate, as well as whole-cell recordings of membrane potential and $\mathrm{pH}$-sensitive background currents, we used pipette solution containing the following (in mM): $120 \mathrm{KCH}_{3} \mathrm{SO}_{3}, 4 \mathrm{NaCl}, 1 \mathrm{MgCl}_{2}, 0.5 \mathrm{CaCl}_{2}, 10$ HEPES, 10 EGTA, 3 Mg-ATP, 0.3 GTP-Tris, pH 7.2 (with KOH). We used a $\mathrm{Cs}^{+}$-based internal solution for voltage-clamp recordings of shRNA effects on NMDG- and SP-sensitive background currents, containing the following (in mM): $104 \mathrm{CsCH}_{3} \mathrm{SO}_{3}, 1 \mathrm{MgCl}_{2}, 0.5 \mathrm{CaCl}_{2}, 30$ TEACl, 10 HEPES, 10 EGTA, 3 Mg-ATP, 0.3 GTP-Tris, pH 7.2 (with $\mathrm{CsOH}$ ); electrode tips were coated with Sylgard 184 (Dow Corning). TTX $(1 \mu \mathrm{M})$ was added to the bath for voltage-clamp recordings of NMDGand SP-sensitive currents. We used brief bath applications of 5-HT (5 $\mu \mathrm{M})$ and SP $(1 \mu \mathrm{M})$; because of poor wash and likely desensitization, individual slices were exposed to 5-HT and SP only once.

Recordings were performed in either cell-attached or whole-cell configurations at room temperature using pClamp, a Multiclamp amplifier, and a Digidata 1440A analog-to-digital converter (all from Molecular Devices). Cell-attached and whole-cell recordings were made under voltage clamp at a holding potential $\left(V_{\mathrm{h}}\right)$ of $-60 \mathrm{mV}$ (Perkins, 2006); resting membrane potential was obtained from stable interspike intervals shortly after whole-cell access using current-clamp configuration. The $\mathrm{pH}$ sensitivity of individual RTN neurons was assessed by measuring cell-attached firing responses in bath solutions titrated to different $\mathrm{pH}$ levels (from $\mathrm{pH} 7.0$ to $\mathrm{pH} 8.0$ ), and using linear regression analysis to interpolate a $\mathrm{pH}_{50}$ value at which firing was reduced to half that observed at pH 7.0 (Lazarenko et al., 2009). NMDG and SP currents in RTN neurons were characterized under whole-cell voltage clamp at $\mathrm{V}_{\mathrm{h}}=-60$ $\mathrm{mV}$. Effects of NMDG and SP on holding current and conductance were followed over time with repeating voltage steps $(\Delta-50 \mathrm{mV}, 140 \mathrm{~ms}$, $0.067 \mathrm{~Hz}$ ); current-voltage $(I-V)$ relationships were obtained under steady-state conditions with a family of voltage steps $(\Delta 10 \mathrm{mV}$ from -120 to $-40 \mathrm{mV}, 400 \mathrm{~ms}$ ), and the reversal potential of NMDGsensitive currents was estimated from the intersection of linear fits to those $I-V$ curves. All membrane voltages were corrected for a $10 \mathrm{mV}$ liquid junction potential. Compensation for series resistance $(60 \%-$ $70 \%)$ and cell capacitance was obtained using the amplifier circuits. To calculate specific membrane resistance $\left(\mathrm{k} \Omega / \mathrm{cm}^{2}\right)$ from conductance values obtained under voltage clamp, we assumed a specific capacitance of $1 \mu \mathrm{F} / \mathrm{cm}^{2}$.

Lentivirus injection into the RTN of Phox2b::GFP mice. Adult Phox $2 b:: G F P$ mice were anesthetized with ketamine/dexmedetomidine $\mathrm{HCl}(100 \mathrm{mg} / \mathrm{kg}$ and $0.2 \mathrm{mg} / \mathrm{kg}$, i.p.), mounted in a stereotaxic apparatus, and maintained at $37^{\circ} \mathrm{C}$ with a servo-controlled heating pad. After craniotomy, a pipette filled with PRSx8-shRNA-mCherry or PRSx8-scrambled-mCherry lentivirus (diluted to $\sim 2 \times 10^{9} \mathrm{TU} / \mathrm{ml}$ ) was inserted at coordinates $\sim 1.4 \mathrm{~mm}$ lateral to midline, $1.0 \mathrm{~mm}$ caudal to bregma, and $5.2-5.5 \mathrm{~mm}$ ventral to the pial surface of the cerebellum (Paxinos and Franklin, 2001). In addition to stereotaxic coordinates, the tip of the pipette was positioned precisely $100 \mu \mathrm{m}$ below the facial motor nucleus, which was identified by recording antidromic field potentials elicited by stimulating the mandibular branch of the facial nerve (Abbott et al., 2009; Kumar et al., 2015). The glass pipette was connected to an electronically controlled pressure valve (Picospritzer II), and brief pressure pulses (3-6 ms) were used to inject $150 \mathrm{nl}$ of virus bilaterally, at each of 3 rostrocaudally aligned sites separated by $200 \mu \mathrm{m}$. After surgery, mice were treated with ampicillin $(100 \mathrm{mg} / \mathrm{kg}$, s.c.), atipamezole $(2 \mathrm{mg} / \mathrm{kg}$, s.c.), and ketoprofen ( $4 \mathrm{mg} / \mathrm{kg}$, s.c.). At least 4 weeks elapsed following virus injection before mice were examined in ventilatory and histochemical assays.

Breathing measurements. Ventilatory responses were measured in conscious, unrestrained mice by whole-body plethysmography (EMKA 
A in situ hybridization in Phox2b::GFP mice
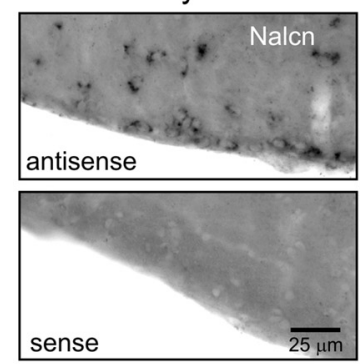

C
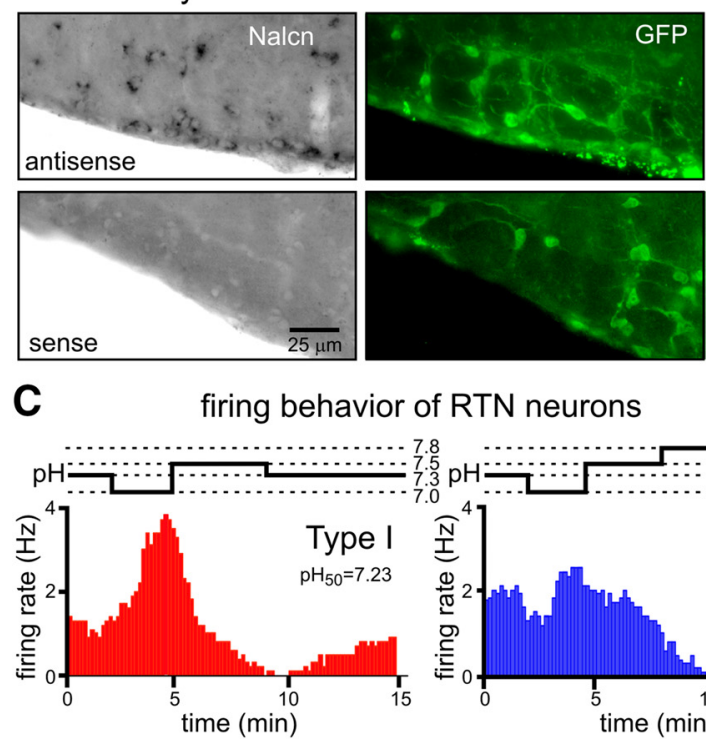

firing behavior of RTN neurons
B
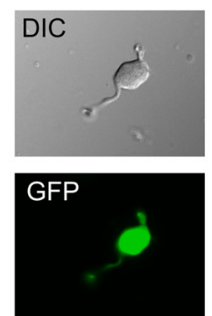

D Nalcn expression in RTN neurons single cell multiplex PCR

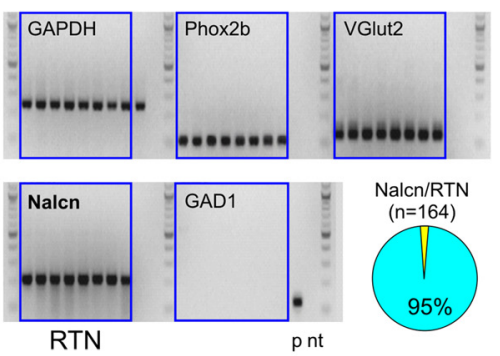

$4 \% 7$ o Type I
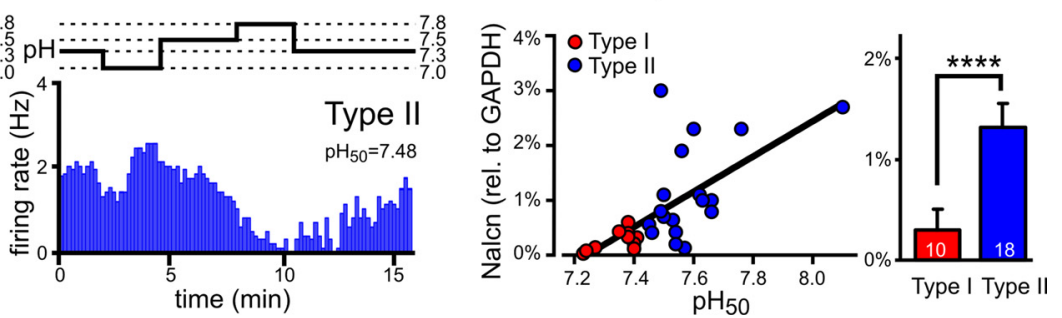

Figure 1. Nalcn is expressed at variable levels in RTN neurons. $\boldsymbol{A}$, In situ hybridization for Nalcn transcripts and immunohistochemistry for GFP in RTN neurons from Phox2b::GFP mice. $\boldsymbol{B}$, GFP-labeled RTN neurons acutely dissociated from acute slices (left) were harvested for multiplex, nested sc-PCR (right). Phox2b- and VGlut2-expressing RTN neurons also expressed Nalcn (boxed); fractional Nalcn expression for all cells tested $(n=164)$. GAD1 was detected in pooled non-GFP neurons ( $(p)$; amplicons were not detected in control reactions with no template ( $n t)$. C, Firing rate histograms from exemplar GFP-labeled RTN neurons recorded in acute slices depicting effects of bath pH on discharge in cells that were characterized as either Type I $\left(\mathrm{pH}_{50}=7.23\right)$ or Type II ( $\mathrm{pH}_{50}$, 7.48). D, Left, Correlation between Nalcn expression levels (by sc-qPCR, normalized to GAPDH) and $\mathrm{pH}_{50}$ values in individual recorded RTN neurons $\left(R^{2}=0.46, p<0.0001\right)$. Right, Nalcn expression in Type I $\left(\mathrm{pH}_{50} \leq 7.42, n=10\right)$ and Type II $\left(\mathrm{pH}_{50}>7.42, n=18\right)$ RTN neurons. ${ }^{* *} p<0.0001$ (unpaired $t$ test).

Technologies) (Kumar et al., 2015). A mass flow regulator provided quiet, constant, and smooth flow through the animal chamber $(0.5$ $\mathrm{L} / \mathrm{min}$ ). We habituated mice to the plethysmography chamber for $4 \mathrm{~h}$ before testing. The protocol entailed three sequential incrementing $\mathrm{CO}_{2}$ challenges ( 7 min exposures to $4 \%, 6 \%, 8 \% \mathrm{CO}_{2}$, balance $\mathrm{O}_{2}$; each separated by $5 \mathrm{~min}$ of $100 \% \mathrm{O}_{2}$ ). Hypercapnic exposure was performed in hyperoxia to minimize contributions of peripheral chemoreceptors to the hypercapnic ventilatory reflex (Basting et al., 2015) and attribute ventilatory effects to central chemoreceptors. For hypoxia challenges, mice were exposed to $10 \% \mathrm{O}_{2}$, balance $\mathrm{N}_{2}$ for up to $15 \mathrm{~min}$.

Analysis of responses to ventilatory challenge. Ventilatory flow signals were recorded, amplified, digitized, and analyzed using Iox 2.7 (EMKA Technologies) to determine ventilatory parameters over sequential $20 \mathrm{~s}$ epochs ( $\sim 50$ breaths), during periods of behavioral quiescence and regular breathing. Minute ventilation $\left(\mathrm{V}_{\mathrm{E}}, \mathrm{ml} / \mathrm{min} / \mathrm{g}\right)$ was calculated as the product of respiratory frequency ( $\mathrm{fR}$, breaths/min) and tidal volume $\left(\mathrm{V}_{\mathrm{T}}, \mathrm{ml} /\right.$ breath $)$, and normalized to body weight $(\mathrm{g})$. For analysis of the acute hypercapnic ventilatory response, we sampled 10 consecutive epochs ( $200 \mathrm{~s}$, representing $\sim 400-500$ breaths at rest) that showed the least interbreath irregularity during the steady-state plateau period after each $\mathrm{CO}_{2}$ exposure, as determined by Poincaré analysis (Loria et al., 2013; Kumar et al., 2015). The response to hypoxia was determined from the peak $\mathrm{V}_{\mathrm{E}}(20 \mathrm{~s}$ epoch $)$ during the hypoxic exposure (Kumar et al., 2015).

In vivo hypercapnia-induced cFos expression. In vivo activation of RTN neurons by $\mathrm{CO}_{2}$ was assessed in adult Phox $2 b::$ GFP mice (P60-P100) by cFos expression (Kumar et al., 2015). Mice were habituated to the plethysmography chamber for $4 \mathrm{~h}$ on the day before the experiment. Mice were then exposed to $2 \mathrm{~h}$ hyperoxia, and then the $8 \% \mathrm{CO}_{2}$ stimulus (hypercapnia) for $45 \mathrm{~min}$, followed by $45 \mathrm{~min}$ of hyperoxia. Following this, mice were anesthetized with ketamine and xylazine $(200 \mathrm{mg} / \mathrm{kg}$ and $14 \mathrm{mg} / \mathrm{kg}$, i.p.) and perfused transcardially with $4 \% \mathrm{PFA} / 0.1 \mathrm{~m}$ phosphate buffer (PB). Brainstems were cut on a vibrating microtome (Leica) into $30 \mu \mathrm{m}$ transverse sections and immunostained for fluorescence markers, GFP and mCherry (primary: chicken anti-GFP, Aves Laboratories, GFP-1020; rabbit anti-DsRed, Clontech, 632496; secondary: donkey anti-chicken Alexa488, Jackson ImmunoResearch Laboratories, 703-545-155; donkey anti-rabbit Cy3, Jackson ImmunoResearch Laboratories, 711-166-152), followed by overnight incu- bation with c-Fos primary antibody (goat anti-cFos, Santa Cruz Biotechnology, sc-52-G); sections were then incubated for $1 \mathrm{~h}$ with biotinylated secondary antibody (donkey anti-goat, Jackson ImmunoResearch Laboratories, 705-065-147) and avidin-HRP (Vector Laboratories, PK6100) for 45 min followed by development of nickel-intensified 3, 3' -diaminobenzidine reaction product.

Combined in situ hybridization and immunohistochemistry. Mice were perfused transcardially with $4 \% \mathrm{PFA} / 0.1 \mathrm{M} \mathrm{PB}$ and brainstems cut in the transverse plane ( $30 \mu \mathrm{m})$; RNA probe production, tissue preparation, and staining procedure followed published protocols (Kumar et al., 2012). Nalcn, VGlut2, and NK1R transcript expression was assessed using cRNA probes (Nalcn: 1805 bp, from nucleotide 4734 of NM_177393; VGlut2: 1195 bp, from nt 1085 of NM_080853; NK1R: 926 bp, starting from nt 1 of NM_009313). Briefly, DNA fragments were amplified from mouse brain with primers that included T7 and SP6 polymerase promoter sequences and used as templates for digoxigenin (DIG)-labeled RNA probe synthesis. The hybridization step was performed with $0.5 \mu \mathrm{g} / \mathrm{ml}$ of DIG-labeled RNA probe, and subsequently the tissue was incubated for $48 \mathrm{~h}$ at $4^{\circ} \mathrm{C}$ with an alkaline phosphatase-conjugated antibody to DIG (sheep anti-DIG, Roche, 11093274910 ) and primary antibodies for GFP and/or DsRed (as above). Subsequently, the sections were incubated for $2 \mathrm{~h}$ at room temperature in secondary antibodies for detection of GFP and DsRed (as above), and hybridization signal was detected using alkaline phosphatase substrate, 4-nitroblue tetrazolium/5-bromo-4-chloro-3-indolyl-phosphate solution. Sense probes were used as negative control.

Cell counts and analysis. Serial sections (1:3 series) through the rostrocaudal extent of the RTN were mounted on glass slides, and images were acquired using an epifluorescence microscope (Zeiss Axioimager Z1) equipped with Neurolucida software. Labeled neurons were counted and aligned for averaging according to defined anatomical landmarks (Paxinos and Franklin, 2001). No stereological correction factor was applied; therefore, actual cell numbers will be $\sim 3$ times higher than counted. The investigator assessing and quantifying cellular profiles was blinded to treatment.

Statistics. Results are presented as mean \pm SEM. All statistical analyses were performed using GraphPad Prism (version 6.07); details of specific tests are provided in the text or figure legends. Statistical significance was set at $p<0.05$. 
A

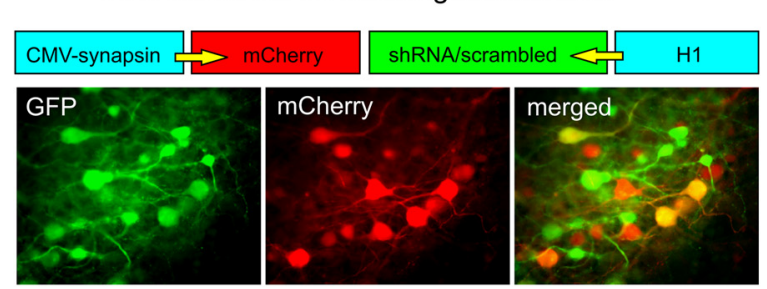

C
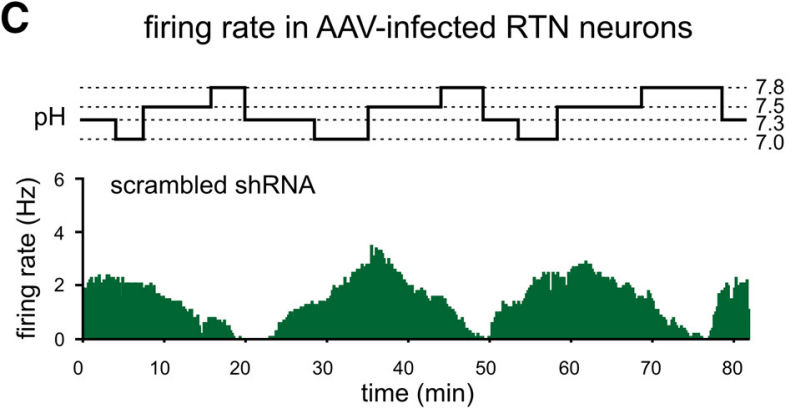

D
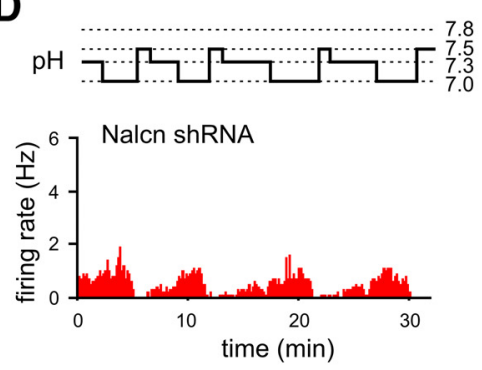

$E$

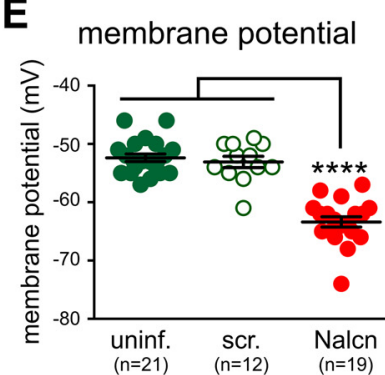

B

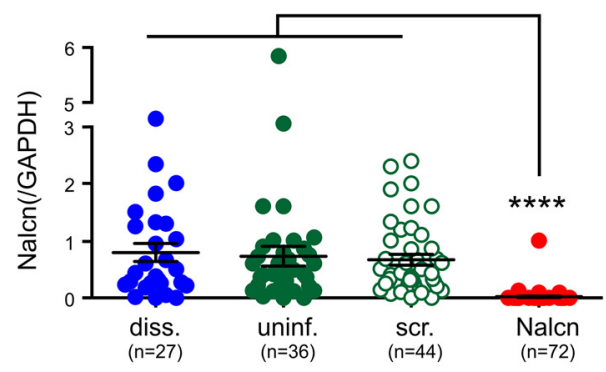

F

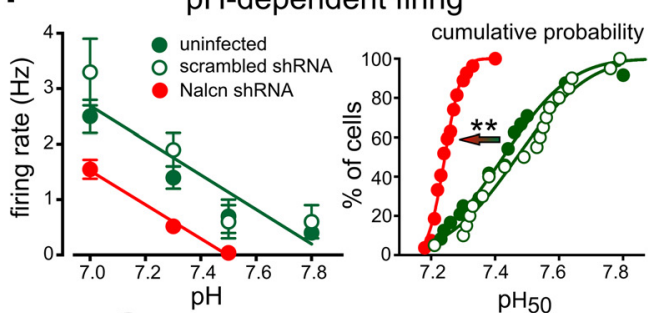

G

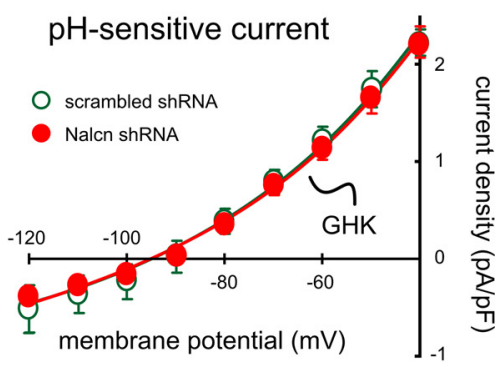

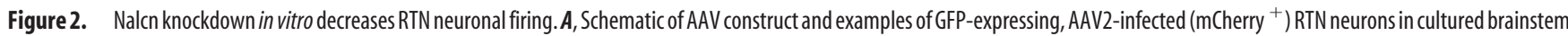
slice. $\boldsymbol{B}$, Nalcn expression determined by sc-qPCR in all RTN neurons tested (relative to GAPDH). This complete dataset includes acutely dissociated GFP-labeled RTN neurons (diss); it also includes RTN neurons from cultured slices that were uninfected (uninf) or infected with scrambled (scr) or Nalen shRNA that were harvested after dissociation or after electrophysiological recording. ${ }^{* * * *} p<$ 0.0001 (ANOVA with pairwise post hoc comparisons by Bonferroni test). C, D, Cell-attached recording of effects of changing bath pH on firing rate in RTN neurons infected with AAV2 for scrambled control shRNA (C) or Nalcn shRNA (D). E, Resting membrane potential was determined under whole-cell current-clamp conditions in a subset of cells following cell-attached recordings. ${ }^{* * * *} p<$ 0.0001 (ANOVA with pairwise post hoc comparisons by Bonferroni test). $\boldsymbol{F}$, Effect of bath $\mathrm{pH}$ on firing rate of RTN neurons determined by cell-attached recording in cultured slices. Left, The slopes of best fit regression lines for control (uninfected and scrambled shRNA) and Nalcn shRNA-expressing RTN neurons were not different; the control line was shifted significantly toward higher firing rates $(p<0.01)$. Right, Cumulative probability histogram of $\mathrm{pH}_{50}$ values for control RTN neurons (green represents uninfected, $n=28$; white represents scrambled shRNA, $\left.n=24\right)$ and for RTN neurons expressing Nalcn shRNA (red represents $n=34$ ). Overlaid line is best fit Gaussian curve. ${ }^{* *} p<0.01$ (Kolmogorov-Smirnov test). $\mathbf{G}$, Whole-cell voltage-clamp steps were used to characterize the pH-sensitive background $\mathrm{K}^{+}$current by digital subtraction (pH 7.8- pH 7.0) in RTN neurons expressing either scrambled $(n=5)$ or Nalcn shRNA $(n=4)$; fits to the Goldman-Hodgkin-Katz (GHK) equation for a $\mathrm{K}^{+}$-selective current are overlaid.

\section{Results}

Nalcn is expressed at variable levels in chemosensitive RTN neurons

In Phox $2 b::$ GFP mice, virtually all GFP-labeled cells in the RTN express Phox $2 \mathrm{~b}$ and are $\mathrm{CO}_{2} / \mathrm{H}^{+}$-sensitive, firing at higher rates during extracellular acidification and lower rates during alkalization (Lazarenko et al., 2009). By combining immunostaining for GFP with in situ hybridization for detection of Nalcn transcripts, we found that most GFP-labeled RTN neurons located at or near the ventral medullary surface express Nalcn (Fig. $1 A$ ); cell counts revealed that $\sim 90 \%$ of RTN neurons express Nalcn in neonatal $(90.7 \pm 0.4 \%, n=4)$ and adult mice $(89.7 \pm 0.4 \%, n=12)$. In addition, by multiplex sc-PCR from GFP-labeled cells dissociated from neonatal mice (Fig. $1 B$ ), we identified Nalcn transcripts in $\sim 95 \%$ of Phox 2 b- and VGlut2-expressing RTN neurons $(n=$ 156/164, from 24 mice).

We tested whether naturally varying levels of Nalcn expression are associated with different neuronal firing properties. Using cell-attached recordings in acute slice preparations (in the continued presence of fast synaptic blockers), RTN neurons were identified that differed in the $\mathrm{pH}$ range over which they maintain their discharge (Fig. 1C); this was reflected in their $\mathrm{pH}_{50}$ values (the $\mathrm{pH}$ at which action potential discharge drops to $50 \%$ of that obtained at $\mathrm{pH}$ 7.0) (Lazarenko et al., 2009). Following functional characterization, whole-cell access was obtained and the contents of the recorded neurons were aspirated into the recording pipette to measure Nalcn transcript levels by sc-qPCR. There was a strong positive correlation between higher $\mathrm{pH}_{50}$ values and Nalcn expression levels (Fig. 1D, left). Using a previously established $\mathrm{pH}_{50}$ cutoff (Lazarenko et al., 2009), we classified RTN neurons with $\mathrm{pH}_{50}<7.42$ as Type $\mathrm{I}$ and those with $\mathrm{pH}_{50}>7.42$ as Type II; Nalcn expression was significantly higher in Type II RTN neurons (Fig. 1D, right).

\section{Knockdown of Nalcn in vitro decreases basal discharge of RTN neurons}

For a more direct test of Nalcn contributions to RTN neuronal function, we developed a viral-mediated shRNA strategy for depleting Nalcn from neurons maintained in slice culture. From multiple candidates, we identified a previously described shRNA 
A

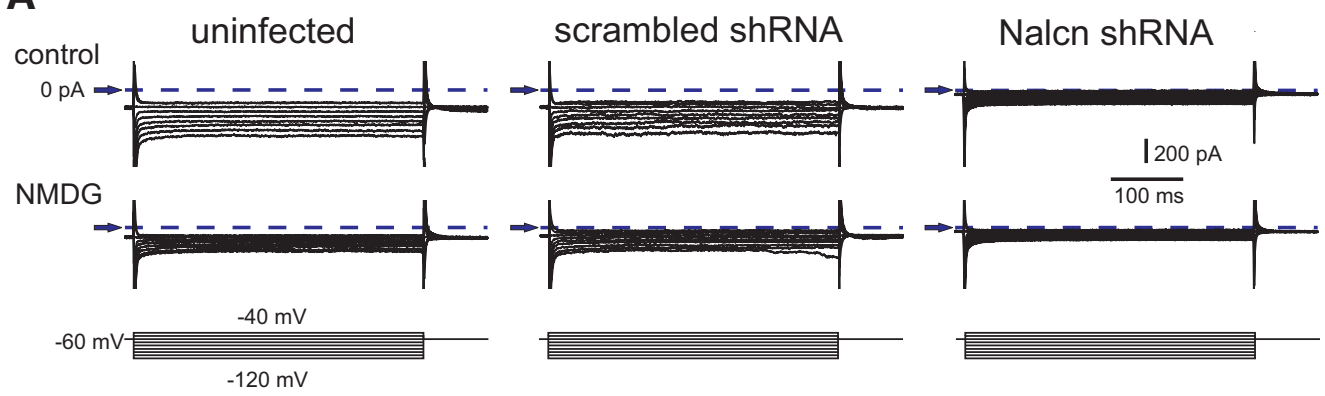

B
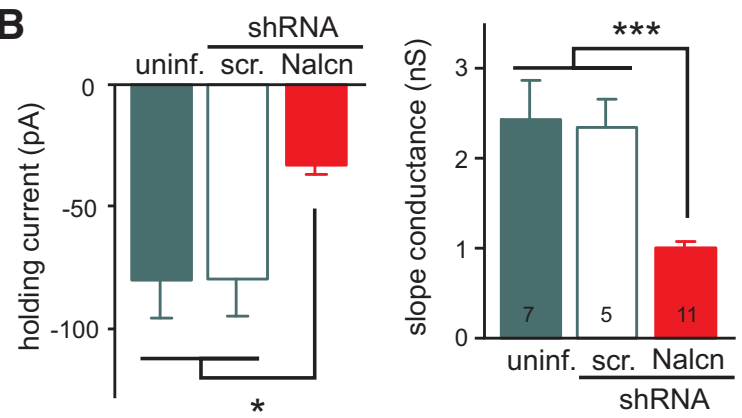

D

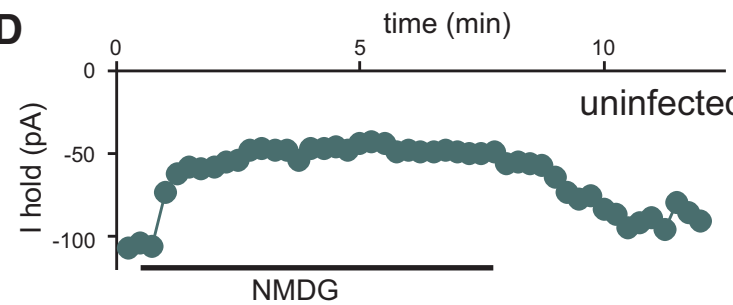

E
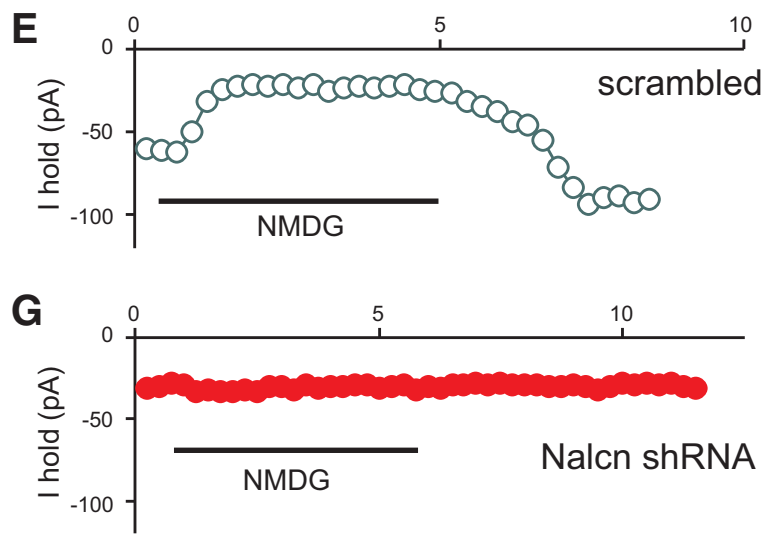

I

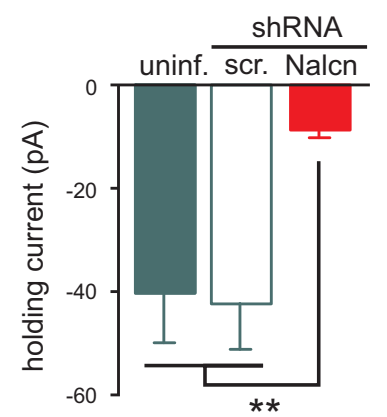

C

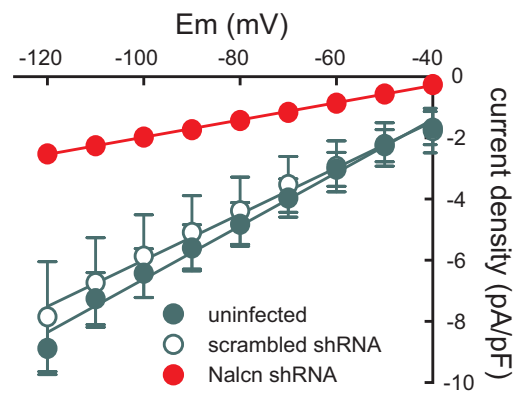

$\mathbf{F}$

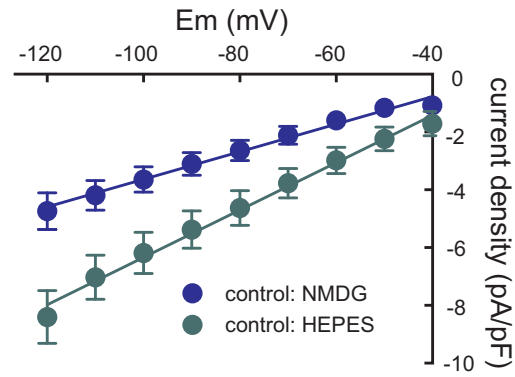

H

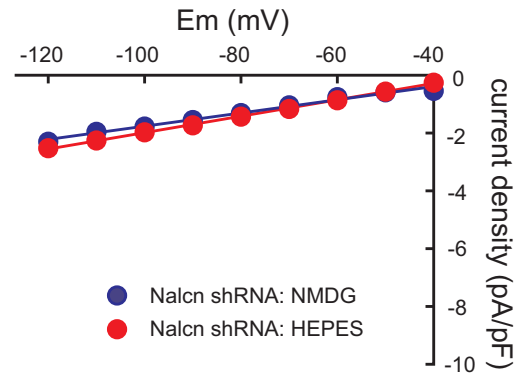

J Nalcn (rel. to GAPDH)

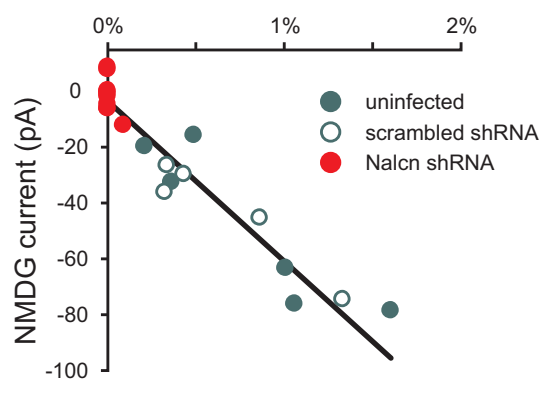

Figure 3. Nalcn knockdown in vitro reduces a TTX-resistant leak Na ${ }^{+}$current. $A$, Whole-cell voltage-clamp recordings of membrane currents with (s-based internal solution in RTN neurons that were uninfected, or infected with either scrambled shRNA or Nalcn shRNA under control conditions (Na-HEPES bath solution) or in a bath solution that replaced Na (Figure legend continues.) 
construct that reduced expression of cotransfected recombinant Nalcn in HEK293 cells by 70\% (Lee et al., 1999; Swayne et al., 2010). This shRNA species and its scrambled control were incorporated downstream of a PolIII (H1) promoter into selfcomplementary AAV targeting vectors that also included a CMVsynapsin promoter to drive neuronal mCherry expression (Fig. 2A). The corresponding AAV (serotype 2) virus was applied to the media of cultured brainstem slices, and infected neurons were identified in the RTN region by coexpression of GFP and mCherry from 2 to 4 weeks after infection (Fig. 2A). We used sc-qPCR to verify that Nalcn expression was strongly reduced in shRNA-expressing RTN neurons compared with uninfected cells, RTN neurons expressing scrambled shRNA, or RTN neurons dissociated from acute slices (Fig. 2B).

We performed cell-attached recordings of firing behavior from RTN neurons expressing either Nalcn or control shRNA. Cells infected with Nalcn shRNA-expressing virus had significantly lower firing rates under baseline conditions (Fig. 2C,D) and ceased discharge at relatively mild levels of alkalization compared with scrambled shRNA-expressing or uninfected RTN neurons. After recording $\mathrm{pH}$ effects on firing rate, we obtained whole-cell current recordings in a subset of these cells and found that Nalcn-depleted RTN neurons had a significantly more negative resting membrane potential than control cells (Fig. 2E). Nalcn depletion shifted $\mathrm{pH}_{50}$ values to more acidified levels (Fig. $2 F$ ). This shift reflects the lower initial firing rate observed in Nalcn-depleted RTN neurons, rather than a difference in intrinsic neuronal $\mathrm{pH}$ sensitivity, because there was no difference in $\mathrm{pH}$ effects on firing in control or Nalcn shRNA-expressing neurons (i.e., slopes: $-2.9 \pm 0.6 \mathrm{~Hz} / \mathrm{pH}$ vs $-2.6 \pm 0.3 \mathrm{~Hz} / \mathrm{pH}, n=46$ and $n=29, p>0.80$; Fig. $2 F)$ and the $\mathrm{pH}$-sensitive background $\mathrm{K}^{+}$ current in RTN neurons was unaffected by Nalcn knockdown (Fig. 2G). The effects of Nalcn depletion on firing are likely underestimated because we excluded silent RTN neurons that failed to discharge even in acidified bath solutions, $\mathrm{pH} 7.0$, a population that was higher after Nalcn knockdown (Nalcn shRNA: 15.4\% silent, $n=24 / 156$; control cells: $2.4 \%$ silent, $n=3 / 125 ; p<$ 0.0002 by $\chi^{2}$ ). As expected, Nalcn expression was also eliminated in a subset of RTN neurons infected with Nalcn shRNA virus that were processed for sc-qPCR after recording (data not shown). Thus, Nalcn knockdown hyperpolarizes RTN neurons and decreases their basal discharge.

\footnotetext{
$\leftarrow$

(Figure legend continued.) with NMDG. Arrows indicate zero current; capacitive transients truncated for presentation. $\boldsymbol{B}$, Holding current (at $-60 \mathrm{mV}$ ) and input conductance for control RTN neurons (uninfected, $n=7$; or scrambled shRNA, $n=5$ ) and for RTN neurons expressing Nalcn shRNA ( $n=11) .{ }^{*} p<0.05$ (ANOVA, pairwise post hoc comparisons by Bonferroni test). ${ }^{* * *} p<0.001$ (ANOVA, pairwise post hoc comparisons by Bonferroni test). C, Current-voltage (I-V) plot for control (uninfected, $n=8 ;$; crambled shRNA, $n=6$ ) and Nalcn shRNA-expressing RTN neurons $(n=15)$; currents normalized to cell capacitance (current density, pA/pF). D, E, G, Effect of $\mathrm{Na}^{+}$substitution (with NMDG) on holding current in exemplar RTN neurons that were uninfected $(\boldsymbol{D})$, or expressing either scrambled shRNA $(\boldsymbol{E})$ or Nalcn shRNA $(\boldsymbol{G}) . \boldsymbol{F}, \boldsymbol{H}, I-V$ curves illustrating effects of $\mathrm{Na}^{+}$substitution for control RTN neurons ( $\boldsymbol{F}$; data pooled from uninfected and scrambled shRNA-expressing cells, $n=14$ ) and for RTN neurons expressing Nalcn shRNA $(\boldsymbol{H}, n=15)$; currents normalized to cell capacitance (current density, pA/pF). I, NMDG-sensitive holding current (at $-60 \mathrm{mV}$; left) and input conductance (right) for control RTN neurons (uninfected, $n=7$; scrambled shRNA, $n=5$ ) and for RTN neurons expressing Nalcn shRNA ( $n=$ 11). ${ }^{* *} p<0.01$ (ANOVA, pairwise post hoc comparisons by Bonferroni test). ${ }^{* * *} p<0.001$ (ANOVA, pairwise post hoc comparisons by Bonferroni test). J, Correlation between Nalcn expression levels (by sc-qPCR, normalized to GAPDH) and NMDG-sensitive current amplitude for individual RTN neurons $\left(n=6, n=5\right.$, and $\left.n=7 ; R^{2}=0.86, p<0.0001\right)$.
}

\section{Knockdown of Nalcn decreases a TTX-resistant background $\mathrm{Na}^{+}$current in RTN neurons}

We made whole-cell voltage-clamp experiments in cultured slices to assess effects of Nalcn knockdown on TTX-resistant inward current in RTN neurons (Fig. 3A). At a holding potential of $-60 \mathrm{mV}$ in the presence of TTX, Nalcn-depleted neurons displayed a significantly lower inward current compared with control cells that were either uninfected or expressing scrambled shRNA (Fig. 3A-C); when corrected for cell size (i.e., capacitance), the inward current density after Nalcn knockdown was also lower than in uninfected or scrambled shRNA-infected RTN neurons cells (Fig. $3 C$; at $-60 \mathrm{mV}$ : $-0.9 \pm 0.1 \mathrm{pA} / \mathrm{pF}$ vs $-2.7 \pm 0.5 \mathrm{pA} / \mathrm{pF}$ or $-2.7 \pm 0.9 \mathrm{pA} / \mathrm{pF}$; $n=11,7$ and $5, p<0.01)$. Likewise, input conductance was significantly lower in Nalcn shRNA-expressing RTN neurons than in control cells (Fig. $3 A, B ; 1.0 \pm 0.1 \mathrm{nS}$ vs $2.4 \pm 0.4 \mathrm{nS}$ or $2.3 \pm 0.3 \mathrm{nS} ; n=11, n=7$, and $n=5, p<0.0001$ ), with a clear decrease in slope of the averaged whole-cell current densityvoltage relationship $(I-V)$ (Fig. 3C). In cells depleted of Nalcn, specific membrane resistance was $\sim 2$ - to 3 -fold greater than in either group of control cells $\left(39.0 \pm 3.7 \mathrm{k} \Omega / \mathrm{cm}^{2}\right.$ vs $13.6 \pm 1.9$ or $17.0 \pm 4.6 \mathrm{k} \Omega / \mathrm{cm}^{2} ; n=11, n=7$, and $n=5$, $p<0.0001)$

We substituted NMDG for sodium (in bath solutions containing TTX) to examine $\mathrm{Na}^{+}$contributions to the background current reduced by Nalcn knockdown (Fig. 3A, D-H). In uninfected RTN neurons or cells expressing scrambled shRNA, changing from an $\mathrm{Na}^{+}$- to an NMDG-containing bath solution reduced inward holding current and decreased input conductance (Fig. $3 A, D-G$ ). By contrast, NMDG substitution had a much smaller effect on Nalcn shRNAexpressing RTN neurons (Fig. $3 A, G, H$ ). The averaged $I-V$ values were relatively linear through the voltage range tested (Fig. $3 F, H$ ), and the NMDG-sensitive current in control cells reversed at $-20.8 \mathrm{mV}$; both the NMDG-sensitive current and conductance at $-60 \mathrm{mV}$ were significantly lower in Nalcndepleted RTN neurons (Fig. 3I). Moreover, there was a strong correlation between NMDG-sensitive current amplitude and Nalcn expression levels determined by sc-qPCR from the recorded neurons (Fig. $3 J$ ). The residual NMDG-sensitive background current in Nalcn shRNA-expressing cells (Fig. 3I) could reflect incomplete knockdown of Nalcn or expression of alternative TTX-resistant cationic channels that are active near resting membrane potentials (e.g., TRP channels). Nonetheless, the data to this point demonstrate that Nalcn underlies a major, TTX-resistant background $\mathrm{Na}^{+}$current that contributes to basal activity of RTN neurons.

\section{Nalcn underlies a SP-activated background $\mathrm{Na}^{+}$current in RTN neurons}

Nalcn can be activated by neuropeptides, including SP (Lu et al., 2009), and SP strongly excites RTN neurons, both in vitro and in vivo (Mulkey et al., 2007). To determine whether Nalcn contributes to SP-mediated activation of RTN neurons, we tested effects of SP $(1 \mu \mathrm{M})$ on control or Nalcn-depleted cells in slice cultures. In control RTN neurons, SP caused a marked increase in firing rate (Fig. $4 A, C$ ), which was even more pronounced than that seen with bath acidification in the same cells $(\Delta \sim 5-7 \mathrm{~Hz}$ vs $\sim 2 \mathrm{~Hz}$ at $\mathrm{pH} 7.0)$. By contrast, SP had little effect in RTN neurons expressing Nalcn shRNA (Fig. 4A,C). This was not due to the lower initial firing rate because the increased firing evoked by $5 \mu \mathrm{M} 5$-HT, which acts via modulation of KCNQ and HCN channels in RTN neurons (Hawry- 
A
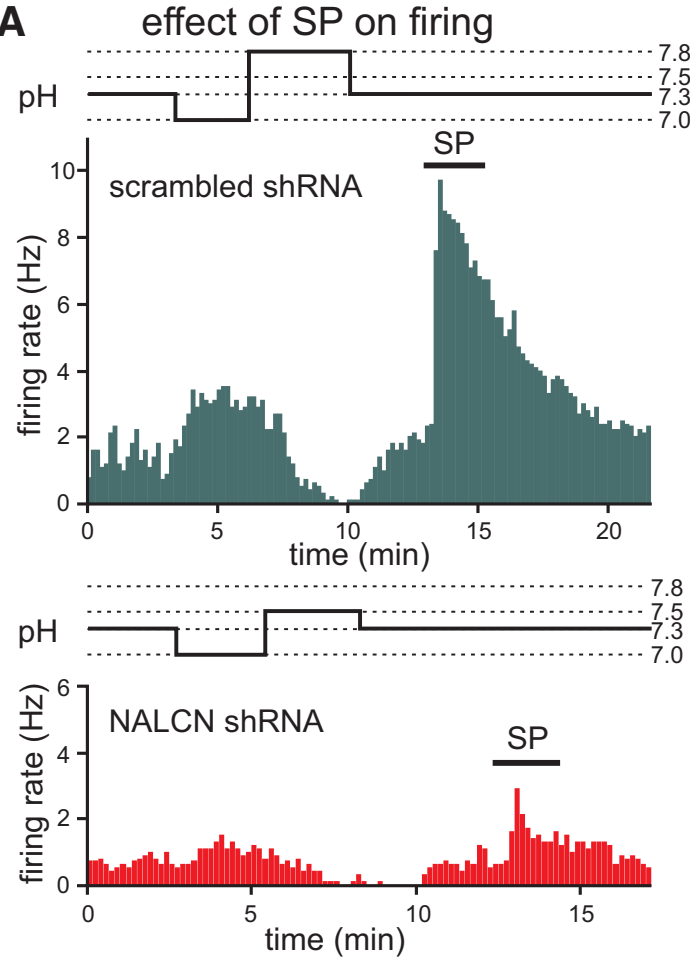

\section{C}

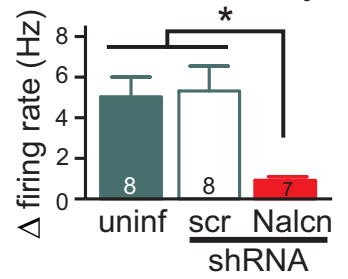

5-HT summary

D

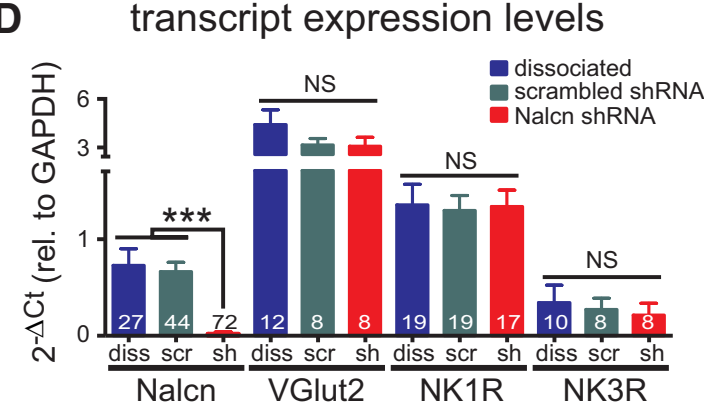

B
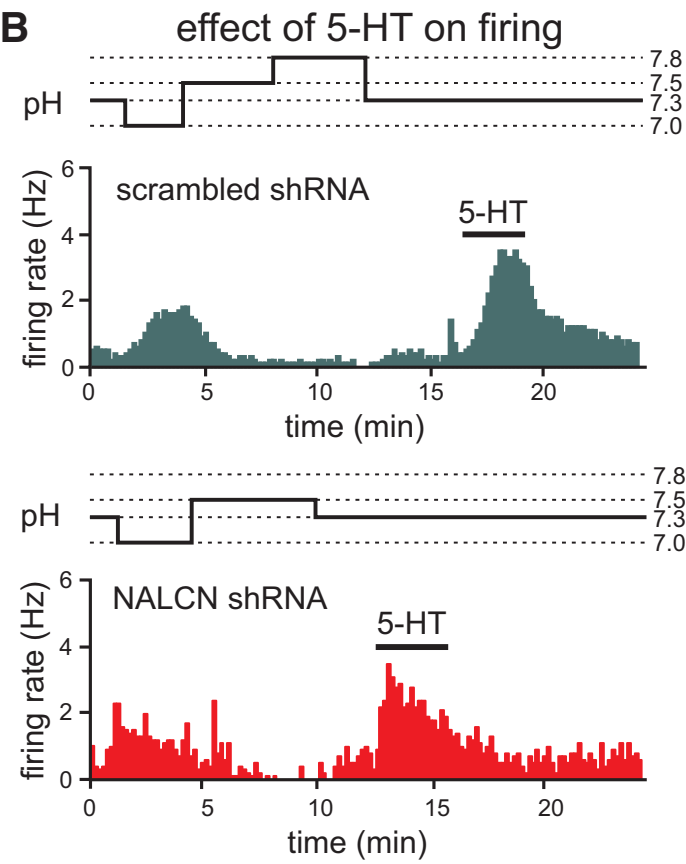

\section{E effect of SP on membrane current} and conductance
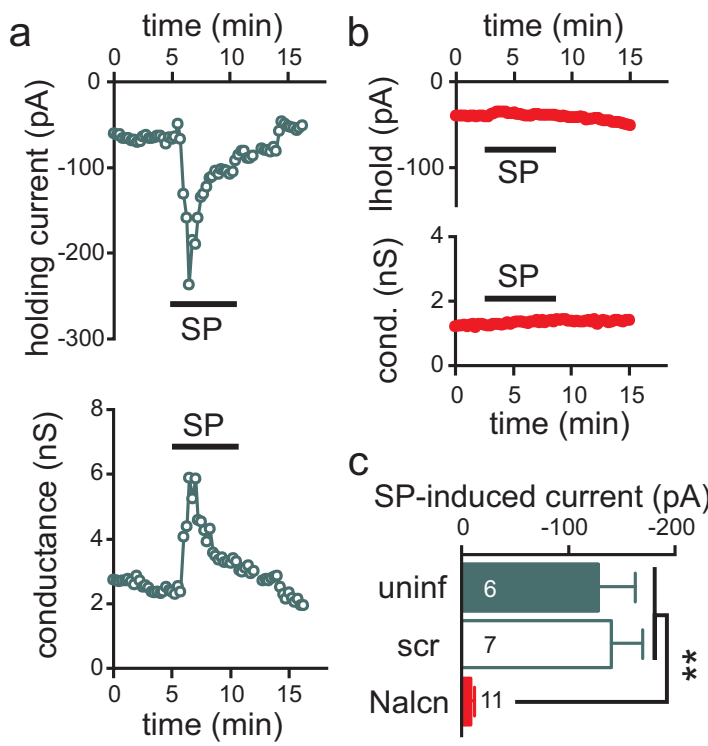

Figure 4. SP activates Nalcn to cause excitation of RTN neurons. A, Cell-attached recording of firing rate during changes in bath pH and application of SP (1 $\mu \mathrm{M}$, bath) in an RTN neuron expressing scrambled control shRNA (top) or Nalen shRNA (bottom). B, Cell-attached recording of firing rate during changes in bath pH and application of 5 -HT ( $5 \mu \mathrm{M}$, bath) in RTN neurons expressing scrambled control shRNA (top) or Nalen shRNA (bottom). C, Summary data of changes in firing rate at pH 7.3 evoked by SP (left) or 5 -HT (right) in control RTN neurons (uninfected or scrambled shRNA) and Nalcn shRNA-expressing RTN neurons. N values provided on plot. ${ }^{*} p<0.05$ (ANOVA, pairwise post hoc comparisons by Bonferroni test). NS, Not significant ( $p>0.49$, ANOVA). $\boldsymbol{D}$, Expression of Nalcn, VGlut2, NK1R, and NK3R determined by multiplex sc-qPCR in RTN neurons in acutely dissociated GFP-labeled RTN neurons (diss) and from RTN neurons expressing scrambled (scr) or Nalcn shRNA (sh) obtained from cultured slices; only Nalcn expression was reduced by Nalcn shRNA. ${ }^{* *} p<0.001$ (ANOVA with pairwise post hoc comparisons by Bonferroni test). $N$ values provided on plot. $E$, Whole-cell voltage-clamp recordings from exemplar RTN neurons expressing scrambled shRNA (Ea) or Nalcn shRNA (Eb) showing SP effects on holding current (top) and input conductance (bottom). Ec, Amplitude of peak SP-induced current in control RTN neurons (uninfected, $n=6$; scrambled shRNA, $n=7$ ) and Nalcn shRNA-expressing RTN neurons $(n=11)$. ** $p<0.01$ (ANOVA, pairwise post hoc comparisons by Bonferroni test).

luk et al., 2012; Hawkins et al., 2015), was unaffected by Nalcn knockdown (Fig. 4B,C). Nalcn expression was eliminated in RTN neurons expressing Nalcn shRNA, with no off-target effects on expression of either NK1R or VGlut2 (Fig. 4D). In addition, there was no effect of Nalcn shRNA on expression of other tachykinin receptors, which were either undetectable (NKA receptor, NK2R, $n=0 / 11$ cells, data not shown) or found at lower levels in a subset of RTN neurons (NKB receptor, NK3R, $\sim 54 \%$ of cells, $n=20 / 37$ ) (Fig. $4 D$ ). Finally, in corroborating voltage-clamp experiments, we found that the SP-sensitive current and SP-activated conductance were strongly reduced by Nalcn knockdown (Fig. 4E). Thus, Nalcn accounts for much of the SP-activated current that excites RTN neurons. 

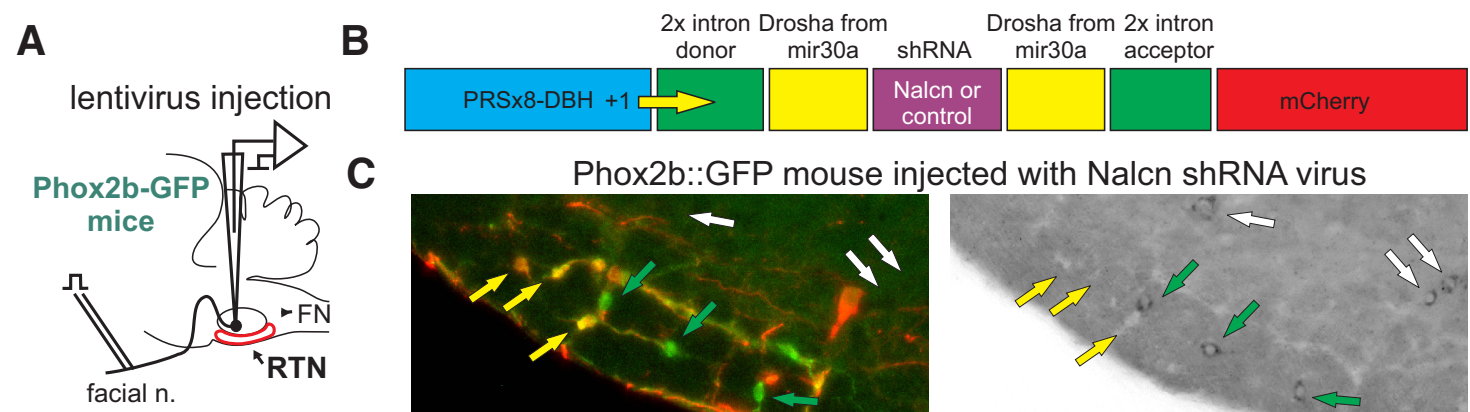

C
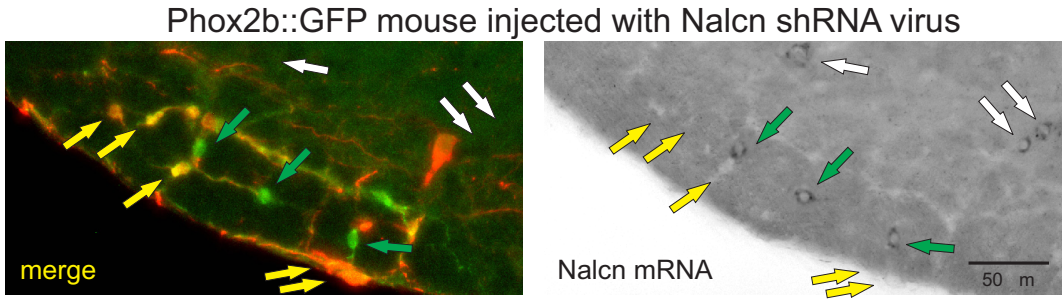

\section{D}

E

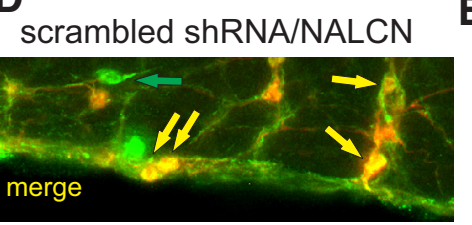

Nalcn shRNA/NK1R
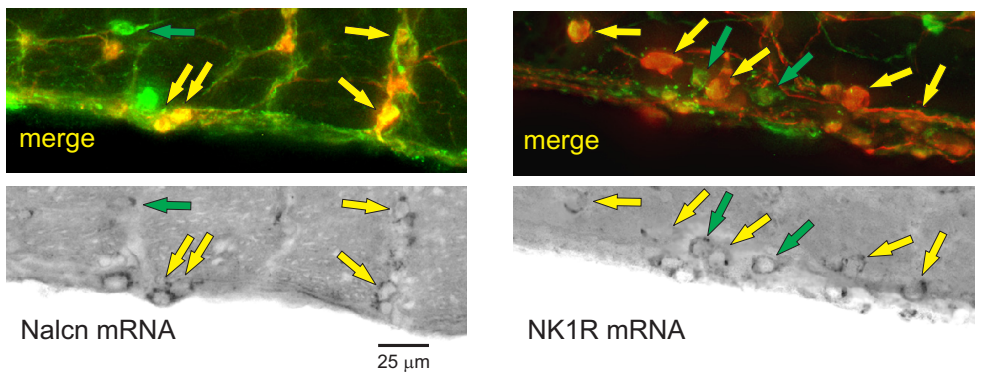

$\mathbf{F}$

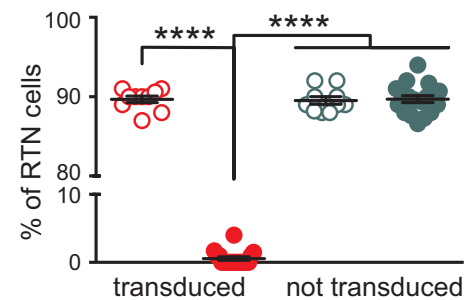

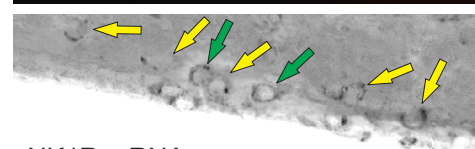

NK1R mRNA
NK1R expression

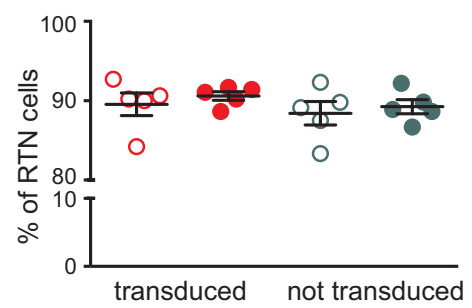

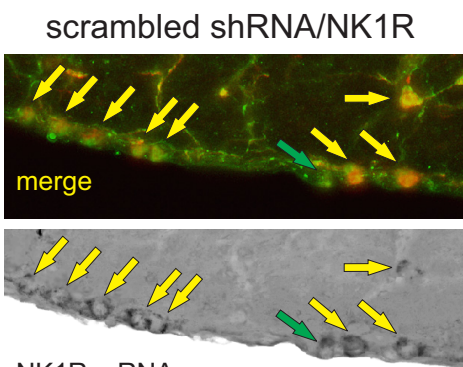

NK1R mRNA
VGlut2 expression

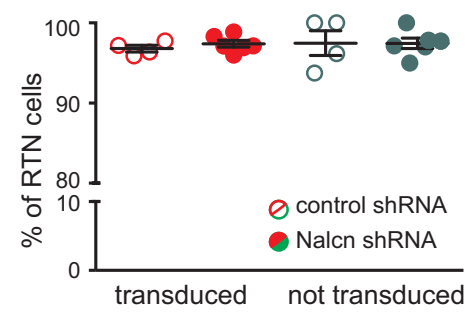

Figure 5. Specific and selective Nalcn knockdown in RTN neurons in vivo. A, Lentivirus was injected into the RTN of Phox2b::GFP mice based on stereotactic coordinates and antidromic field potentials elicited by facial nerve stimulation. B, Schematic of lentiviral construct for expressing Nalcn (or control) shRNA in RTN neurons in vivo. C, Left, Color merge of photomicrographs from GFPand mCherry-immunostained sections depicting RTN neurons that were uninfected (green arrows) or infected with Nalcn shRNA-expressing lentivirus (yellow arrows); uninfected, non-RTN neurons are also apparent (white arrows). Right, Corresponding image from the same section showing Nalcn expression by in situ hybridization. D, Color merge of GFP and mCherry immunostaining (top) and Nalcn in situ hybridization (bottom) from RTN of mouse injected with control shRNA lentivirus. E, Color merge of GFP and mCherry immunostaining (top) and NK1R in situ hybridization (bottom) from RTN of mouse injected with Nalcn (left) or control (right) shRNA lentivirus (arrows in D, E as described in panel $\boldsymbol{C}$ ). $\boldsymbol{F}$, Cell counts through the RTN depicting the percentage of neurons that express the indicated gene (Nalcn, NK1R, or VGlut2, by in situ hybridization), after injection with Nalcn or control shRNA lentivirus; counts include RTN neurons that were either transduced (GFP ${ }^{+} / \mathrm{mCherry}^{+}$) or not transduced (only GFP). Numbers of mice analyzed after receiving Nalcn shRNA or control shRNA: for Nalcn, $n=18$ and $n=10 ;$ for NK1R, $n=5$ each; and for VGlut2, $n=6$ and $n=4$. ${ }^{* * * *} p<$ 0.0001 (ANOVA, pairwise post hoc comparisons by Bonferroni test).

Selective Nalcn depletion from RTN neurons in vivo reduces $\mathrm{CO}_{2}$-evoked neuronal activation and ventilatory stimulation The tonic and $\mathrm{CO}_{2}$-regulated activity of Phox $2 \mathrm{~b}$-expressing RTN neurons provides a major excitatory drive to the brainstem centers that control breathing (Guyenet and Bayliss, 2015). To test a role for Nalcn in RTN-mediated respiratory control, we developed a lentiviral approach for shRNA-mediated knockdown of Nalcn specifically in Phox2b-expressing chemoreceptor RTN neurons in vivo (Fig. $5 A, B$ ). The lentiviral construct incorporates a PRSx8 promoter sequence to direct expression selectively to Phox2b-expressing neurons (Hwang et al., 2001; Abbott et al., 2009) and embeds a Nalcn (or control) shRNA sequence into a Drosha site derived from miR30a in an artificial intron driven by the PRSx8 promoter (McBride et al., 2008; Berger et al., 2010). For a reporter, the mCherry coding sequence was placed downstream of an intron splice acceptor site. Four weeks after bilateral injections of the corresponding lentivirus into the brainstem of anesthetized Phox $2 b:: G F P$ mice, using stereotaxic coordinates and antidromic facial field potentials to localize the RTN region (Abbott et al., 2009; Basting et al., 2015; Kumar et al., 2015), we found mCherry labeling nearly exclusively in GFP-positive RTN neurons (i.e., $98.2 \pm 0.2 \%$ and $97.7 \pm 0.2 \%$ for Nalcn and scrambled virus, $n=15$ each). Viral transduction efficiency within the RTN (i.e., the fraction of $\mathrm{GFP}^{+}$RTN neurons that were also mCherry $^{+}$) ranged from $\sim 20 \%$ to $90 \%$ in individual mice and was not different with Nalcn or scrambled virus $(58.6 \pm 5.9 \%$ vs $64.6 \pm 6.1 \%, n=15$ each, $p>0.48)$.

We used in situ hybridization to evaluate viral-mediated knockdown of Nalcn (Fig. 5C-F). Expression of Nalcn was eliminated specifically in mCherry ${ }^{+}$cells transduced with $\mathrm{Nalcn}$ shRNA (i.e., Fig. $5 C$, yellow arrows; Nalcn labeling in $0.6 \pm 0.2 \%$ of mCherry ${ }^{+}$RTN neurons, $n=15$ mice). By contrast, Nalcn expression was preserved in $\sim 90 \%$ of nearby, uninfected RTN neurons in those same mice (Fig. 5C, green arrows; in $89.7 \pm$ $0.4 \%$ of $\mathrm{mCherry}^{-/ \mathrm{GFP}^{+}}$neurons), and was also evident in nearby cell groups not targeted by the PRSx8 promoter (Fig. 5C, 
A
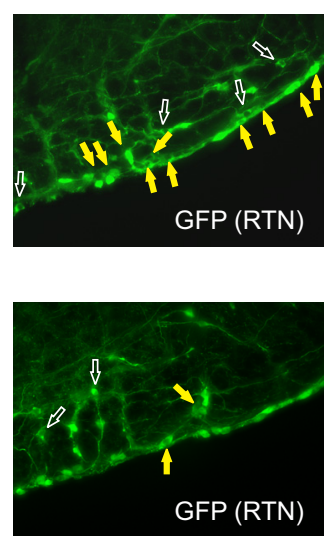

control shRNA

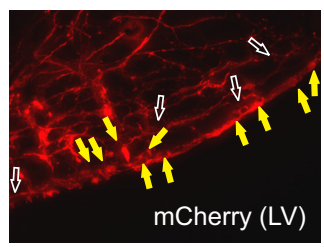

Nalcn shRNA

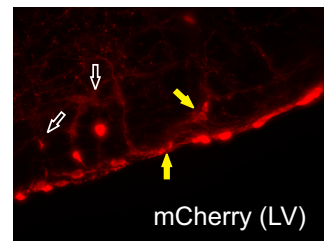

B
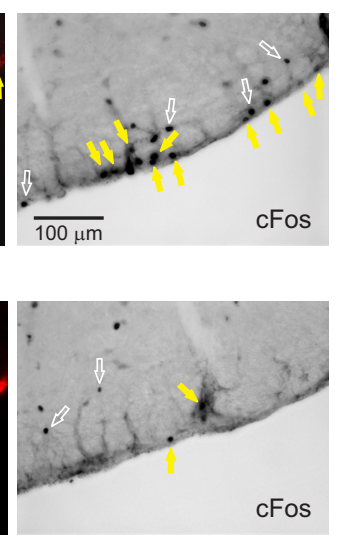

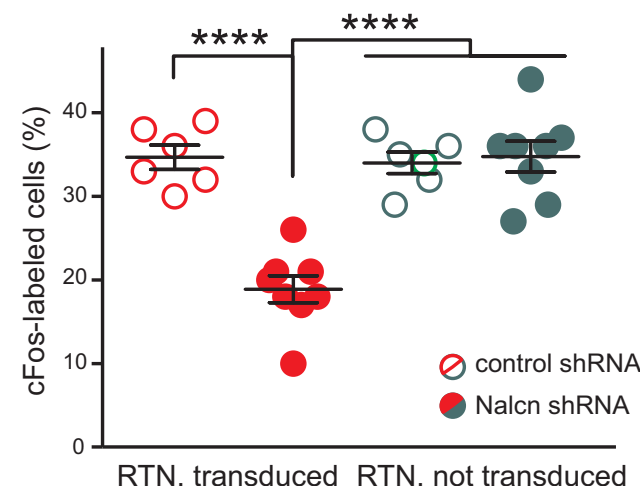

Figure 6. Nalcn knockdown in RTN attenuates $\mathrm{CO}_{2}$-stimulated cFos expression. $\boldsymbol{A}$, cFos expression following exposure to $\mathrm{CO}_{2}(8 \%, 45$ min) in GFP-expressing RTN neurons infected with lentivirus for control (top) or Nalcn shRNA (bottom). Arrows indicate cFos-immunoreactive RTN neurons that were either transduced (yellow) or not transduced (white) with the indicated virus. $\boldsymbol{B}$, Cell counts through the RTN depicting the percentage of cFos-labeled RTN neurons transduced with control or Nalcn shRNA virus compared with nontransduced RTN neurons. ${ }^{* * * *} p<0.0001$ (by AN0VA, pairwise post hoc comparisons by Bonferroni test).

white arrows). Likewise, Nalcn expression was maintained in $\sim 90 \%$ of both infected and uninfected RTN neurons after injection of control shRNA-expressing lentivirus (Fig. 5D, F; $89.7 \pm$ $0.4 \%$ and $89.5 \pm 0.5 \%, n=15$ mice). Importantly, we found no differences in the percentage of RTN neurons expressing NK1R ( $\sim 90 \%)$ or VGlut2 $(\sim 100 \%)$ after injections of either Nalcn or control shRNA virus (Fig. $5 E, F$ ). These data indicate effective and selective knockdown of Nalcn in RTN neurons with this system and support using this viral-based shRNA approach to evaluate Nalcn contributions to RTN function in vivo.

Activation of RTN neurons in vivo by elevated $\mathrm{CO}_{2} / \mathrm{H}^{+}$can be assessed indirectly by expression of cFos (Sato et al., 1992; Kumar et al., 2015). As is typical for RTN neurons in control mice (Kumar et al., 2015), cFos immunoreactivity was found in $~ 35 \%$ of RTN neurons in mice injected with control virus after exposure to $8 \% \mathrm{CO}_{2}$ (Fig. $6 \mathrm{~A}, \mathrm{~B}$ ), regardless of whether or not they were transduced $(34.7 \pm 1.5 \%$ and $34.0 \pm 1.3 \%, n=6$ mice). Likewise, a similar number of nontransduced, cFos-positive RTN neurons were obtained in mice injected with Nalcn shRNA virus (34.7 \pm $1.8 \%, n=8$ mice). However, among RTN cells that were transduced with Nalcn shRNA, only approximately half the number of cFos-labeled neurons were observed $(18.9 \pm 1.6 \%, p<0.0001)$.

Because RTN neuronal activity directly regulates breathing (Abbott et al., 2009; Marina et al., 2010; Basting et al., 2015), we tested whether Nalcn depletion and diminished RTN activation by $\mathrm{CO}_{2}$ would alter in vivo ventilatory responses to raised $\mathrm{CO}_{2}$ (Fig. 7). We used whole-animal plethysmography to determine effects on ventilation of increasing $\mathrm{CO}_{2}$ concentrations in the inspired air (balance $\mathrm{O}_{2}$ ), before and then 4 weeks after injection of Nalcn shRNA (or control) lentivirus into the RTN (Fig. 7A). Under these hyperoxic conditions, carotid body peripheral chemoreceptors are essentially silent and $\mathrm{CO}_{2}$ effects on breathing are primarily determined by brainstem chemoreceptors (e.g., RTN neurons) (Basting et al., 2015). Before virus injection, the effect of $\mathrm{CO}_{2}$ on ventilation $\left(\mathrm{V}_{\mathrm{E}} ; \mathrm{ml} / \mathrm{min} / \mathrm{g}\right)$ was not different in mice that received injections of either Nalcn shRNA or control virus $\left(\Delta \mathrm{V}_{\mathrm{E}} \sim 2.7 \mathrm{ml} / \mathrm{min} / \mathrm{g}\right.$ at $\left.8 \% \mathrm{CO}_{2} ; \mathrm{Fig} .7 \mathrm{~B}, C\right)$. When assessed after Nalcn depletion from RTN neurons, the ventilatory response to $\mathrm{CO}_{2}$ was significantly reduced (by $\sim 37 \%, \sim 1.7 \mathrm{ml} /$ $\mathrm{min} / \mathrm{g}$ ) (Fig. $7 \mathrm{~B}, \mathrm{C}$ ); this was due to diminished $\mathrm{CO}_{2}$-induced increases in both $\mathrm{fR}$ (breaths/min) and $\mathrm{V}_{\mathrm{T}}(\mathrm{ml} /$ breath/g) (Fig.
$7 B)$. Notably, for mice injected with Nalcn shRNA-expressing virus, there was a significant negative correlation between the fraction of virally transduced RTN neurons and the degree of inhibition of $\mathrm{CO}_{2}$-evoked breathing (Fig. 7D). By contrast, $\mathrm{CO}_{2}$ stimulated breathing was unaffected in mice receiving control virus, even at the highest transduction rates (Fig. $7 B-D$ ). Importantly, the stimulation of breathing by reduced $\mathrm{O}_{2}$ was not different before or after either Nalcn or control shRNA virus injection (Fig. 7E), consistent with the minimal contribution from RTN neurons to hypoxic hyperventilation (Basting et al., 2015). Thus, selective Nalcn depletion in RTN neurons decreases $\mathrm{CO}_{2}$-evoked neuronal activation in vivo and strongly blunts $\mathrm{CO}_{2}$-stimulated breathing.

\section{Discussion}

We used shRNA-mediated knockdown of Nalcn, in vitro and in vivo, to demonstrate that Nalcn provides an important "leak" sodium current that regulates basal and neuropeptidemodulated activity in RTN respiratory chemoreceptor neurons and supports $\mathrm{CO}_{2}$-stimulated neuronal activation and respiratory output. We found that shRNA-mediated knockdown of Nalcn did not directly affect the $\mathrm{pH}$-modulated background $\mathrm{K}^{+}$ currents that mediate intrinsic $\mathrm{CO}_{2} / \mathrm{H}^{+}$sensitivity of RTN neurons (Mulkey et al., 2004; Wang et al., 2013a, b; Kumar et al., 2015), but strongly reduced $\mathrm{CO}_{2}$-mediated respiratory responses in vivo. Thus, distinct and functionally antagonistic "leak" currents, carried by $\mathrm{Na}^{+}$and $\mathrm{K}^{+}$, regulate ongoing activity and $\mathrm{CO}_{2}-$ stimulated breathing by RTN chemoreceptor neurons. Moreover, modulation of this channel provides a mechanism for $\mathrm{pH}$-independent stimulation of RTN neuronal activity to influence $\mathrm{CO}_{2}$-dependent control of breathing. Finally, RTN expression of Nalcn may account, in part, for the breathing deficits in global Nalcn knock-out mice (Lu et al., 2007) and contribute to the reported respiratory insufficiencies in some human patients with Nalcn mutations (Chong et al., 2015; Gal et al., 2016).

\section{Regulation of RTN activity by coexpressed leak $\mathrm{Na}^{+}$and $\mathrm{K}^{+}$channels}

Individual $\mathrm{pH}$-sensitive $\mathrm{RTN}$ neurons discharge tonically, both in vivo and in vitro, with different basal firing rates at physiological pH (Mulkey et al., 2004; Lazarenko et al., 2009; Wang et al., 
A

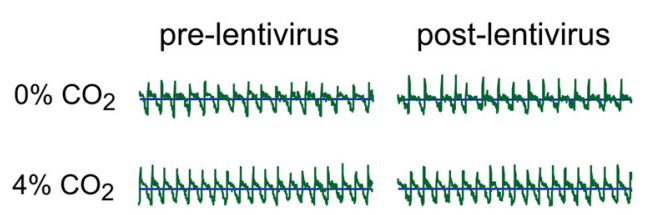

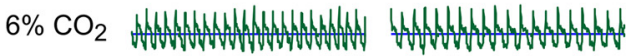

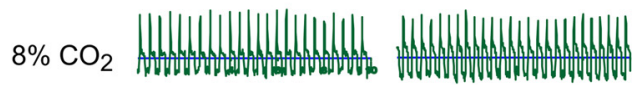

$85 \%$ transduction, $100 \%$ of pre-injection $\Delta V_{E}$
Nalcn shRNA

pre-lentivirus post-lentivirus

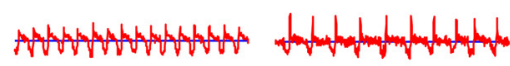

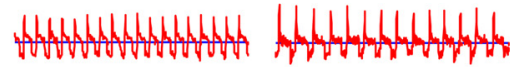
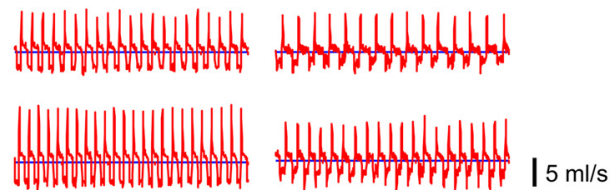

$80 \%$ transduction, $36 \%$ of pre-injection $\Delta V_{E} \quad \overline{2 s}$
B ventilatory response to $\mathrm{CO}_{2}$

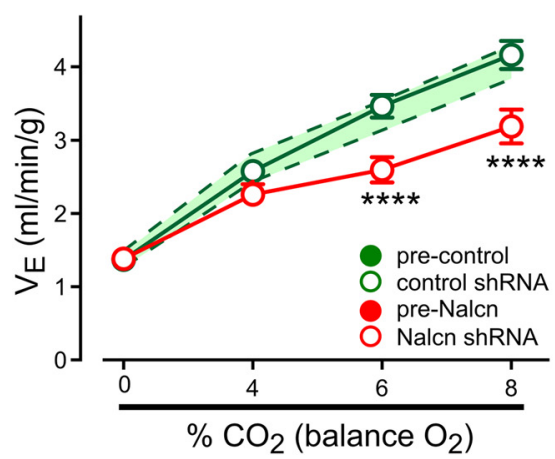

D

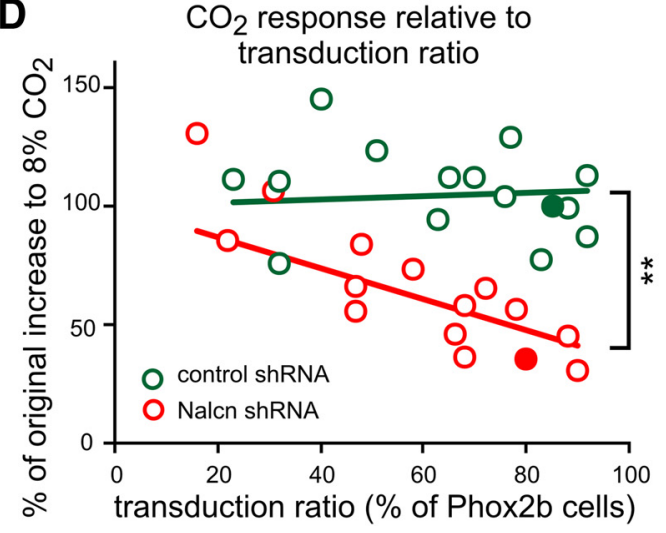

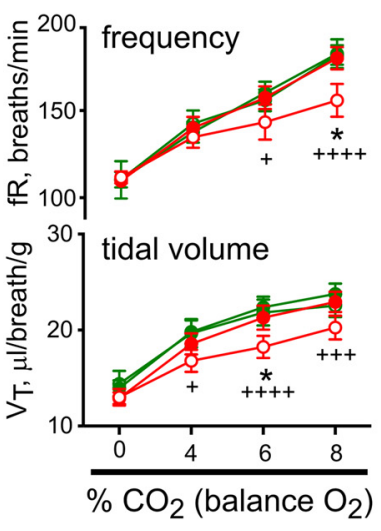

C

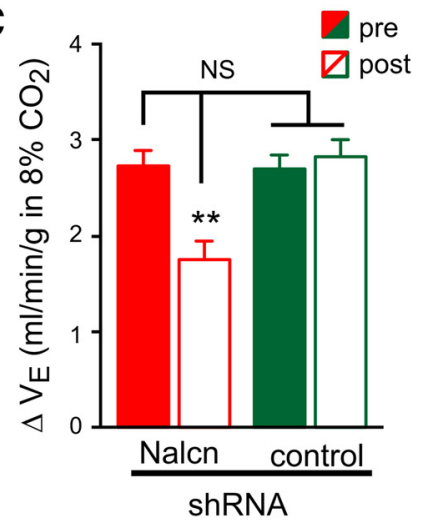

E

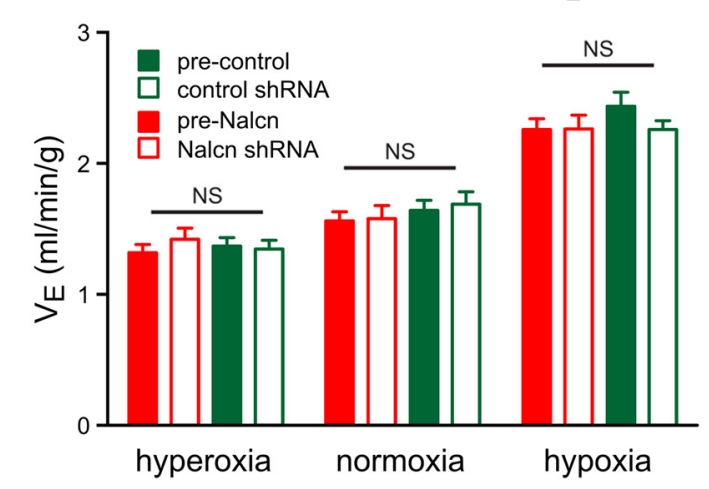

Figure 7. Nalcn knockdown in RTN attenuates $\mathrm{CO}_{2}$-stimulated ventilation. $\boldsymbol{A}$, Example records of respiratory flow data from two individual mice during exposure to gas mixtures with different $\mathrm{CO}_{2}$ concentrations (balance $\mathrm{O}_{2}$ ), before and 4 weeks following injection of lentivirus for control and Nalcn shRNA into the RTN region. The lentiviral transduction ratio and the percentage of preinjection $\Delta \mathrm{V}_{\mathrm{E}}$ at $8 \% \mathrm{CO}_{2}$ is provided for each mouse (also see $\boldsymbol{D}$ ). $\boldsymbol{B}$, Left, Effect of increasing inspired $\mathrm{CO}_{2}$ concentrations on $\mathrm{V}_{\mathrm{E}}$ (the product of breathing frequency, breaths/min, and normalized tidal volume, $\mathrm{ml} / \mathrm{breath} / \mathrm{g}$ ) in mice 4 weeks after injection with control or Nalcn shRNA-expressing lentivirus ( $n=15$ each). Shaded area represents the $95 \%$ confidence for all mice before injection. ${ }^{* * * *} p<0.0001$ versus control virus at 4 weeks (two-way repeated-measures ANOVA, pairwise post hoc comparisons by Bonferroni test). Right, Effect of $\mathrm{CO}_{2}$ on respiratory frequency (fR; breaths $/ \mathrm{min}$ ) and normalized $\mathrm{V}_{\mathrm{T}}(\mathrm{ml} / \mathrm{breath} / \mathrm{g}) 4$ weeks after virus injection in the same control and Nalcn shRNA-expressing mice ( $n=15$ each). Nalcn shRNA versus scrambled shRNA: ${ }^{*} p<0.05$; ${ }^{* * *} p<0.001 ;{ }^{* * * *} p<0.0001$. Nalcn shRNA, before versus after injection: ${ }^{++} p<0.01 ;{ }^{+++} p<0.001 ;{ }^{++++} p<0.0001$; tw0-way repeated-measures AN0VA with pairwise post hoc comparisons by Bonferroni test. $C$, Increase in $\mathrm{V}_{\mathrm{E}}$ in $8 \% \mathrm{CO}_{2}$, before and after injection with control or Nalcn shRNA-expressing lentivirus. ${ }^{* *} p<0.01$ (two-way repeated-measures ANOVA, pairwise post hoc comparisons by Bonferroni test). $D$, Relationship between $\mathrm{RTN}$ transduction ratio and the relative change in response to $\mathrm{CO}_{2}$ for each individual viral-injected mouse. The blunting effect of Nalcn depletion on $\mathrm{CO}_{2}$-stimulated breathing was greater in mice with more infected RTN neurons $\left(R^{2}=0.76\right.$ for Nalcn shRNA, $p<0.0001 ;$ slopes significantly different, $\left.{ }^{* *} p<0.01\right)$. The two filled symbols are data from the exemplar mice shown in $\boldsymbol{A}$. $\boldsymbol{E}$, Effect of changes in inspired $\mathrm{O}_{2}$ concentrations on $\mathrm{V}_{\mathrm{E}}$ (normoxia $=21 \% \mathrm{O}_{2}$, hyperoxia $=100 \% 0$, hypoxia $=10 \% 0$ ) in mice 4 weeks after injection with control or Nalcn shRNA-expressing lentivirus ( $n=15$ each). NS, Not significant.

2013a); these different cellular firing properties presumably permit the population of respiratory chemoreceptor neurons to encode a broad range of ambient $\mathrm{CO}_{2} / \mathrm{H}^{+}$for regulation of breathing in vivo. Our data indicate that $\mathrm{Nalcn}$ is responsible for a prominent leak $\mathrm{Na}^{+}$current in RTN neurons that contributes to these different basal firing rates, providing a depolarizing counterbalance to the background $\mathrm{K}^{+}$currents that account, directly or indirectly, for the intrinsic $\mathrm{pH}$ sensitivity of RTN chemoreceptor neurons (Guyenet and Bayliss, 2015).

Nalcn knockdown led to membrane hyperpolarization and a decrease in RTN neuronal firing activity across the $\mathrm{pH}$ range in vitro, but resting ventilation in vivo was unaffected after Nalcn 
depletion from RTN neurons. This result is not unexpected. Chronic lesion of RTN (and some surrounding) neurons in adult rats using various toxins has relatively modest effects on resting ventilation, apneic threshold, and $\mathrm{CO}_{2}$ sensitivity (Nattie and $\mathrm{Li}$, 2002; Takakura et al., 2008) unless a very high percentage of RTN neurons is eliminated (>70\%) (Takakura et al., 2008). Also, adult mice that survive complete genetic lesion of RTN neurons compensate to maintain normal eupneic ventilation despite a blunted $\mathrm{CO}_{2}$ response (Ramanantsoa et al., 2011). Moreover, lesions of serotonergic neurons that decrease $\mathrm{CO}_{2}$-stimulated breathing to a similar degree were also without effect on breathing parameters at rest (Hodges et al., 2008). Because acute inhibition of RTN neurons reduces eupneic breathing (Basting et al., 2015), Nalcn depletion in RTN likely triggers a compensatory mechanism that can restore adequate ventilation at rest in vivo but is insufficient to elicit normal ventilatory stimulation when the mice are challenged with elevated $\mathrm{CO}_{2}$.

\section{Nalcn modulation and state-dependent regulation of breathing}

We find that Nalcn is responsible, essentially entirely, for the excitatory effects of SP on RTN neurons (Mulkey et al., 2007); after depletion of Nalcn, the SP-evoked increase in firing, inward current, and conductance were nearly completely abolished. This is consistent with earlier reports that neuropeptides, including SP, activate Nalcn in other types of neurons ( $\mathrm{Lu}$ et al., 2009). Interestingly, although $\mathrm{NK}$ and $5-\mathrm{HT}_{2}$ receptors are coexpressed in many RTN neurons and share the same canonical signaling pathway (i.e., G $\alpha$ q-PLC), the effects of 5-HT were unaffected by Nalcn knockdown. Thus, these data imply that 5-HT and SP engage different pathways and/or target different effectors in RTN neurons. Indeed, recent work suggests that 5 -HT acts via $5-\mathrm{HT}_{2}$ and $5-\mathrm{HT}_{7}$ receptors to inhibit KCNQ channels and activate $\mathrm{HCN}$ channels, respectively, via PLC-PKC and cAMP pathways (Hawryluk et al., 2012; Hawkins et al., 2015). By contrast, SP effects are independent of KCNQ channels in RTN neurons (Hawryluk et al., 2012), and NK1R couples to Nalcn via a novel G-protein-independent mechanism involving UNC-80 and Src family kinases in other neurons (Lu et al., 2009). Because the 5-HT and SP input to RTN neurons derives mainly from caudal raphe serotonergic neurons (Hökfeltet al., 1978; Mulkey et al., 2007), these parallel effector mechanisms may support nonocclusive cellular actions under conditions when 5-HT and SP may be coreleased. Moreover, these transmitter actions are independent of the effects of $\mathrm{CO}_{2} / \mathrm{H}^{+}$(Mulkey et al., 2007; Hawryluk et al., 2012; Hawkins et al., 2015), allowing RTN activation by neuromodulatory brain systems to be superimposed on chemoreceptor stimulation.

With respect to SP actions, caudal raphe neurons display an activity pattern that tracks motor behavior (Veasey et al., 1995; Jacobs et al., 2002). In addition, raphe neuronal activity is strongly arousal state-dependent, with high firing rates during active waking and low spike discharge during sleep (Veasey et al., 1995; Jacobs et al., 2002). Likewise, effects of $\mathrm{CO}_{2}$ on breathing are greatest during waking and reduced during sleep (Krieger, 2000; Burke et al., 2015), and patients with central hypoventilation syndrome, associated with Phox $2 \mathrm{~b}$ mutations and reduced $\mathrm{CO}_{2}$ sensitivity) have more severe hypoventilation during sleep (Amiel et al., 2003; Weese-Mayer et al., 2010). Thus, neuromodulation of Nalcn in RTN neurons may contribute, at least in part, to the poorly understood exercise or arousal state-dependent changes in breathing (Guyenet and Bayliss, 2015).
An elegant recent study found that activity of circadian neurons in flies and mice was determined by upregulation and downregulation of $\mathrm{NA} / \mathrm{Nalcn}$ current that was antiphase with expression of a background $\mathrm{K}^{+}$current in those neurons: a higher ratio of $\mathrm{Na}^{+}: \mathrm{K}^{+}$current yielded greater activity during the waking period (Flourakis et al., 2015). The circadiandependent changes in Nalcn activity were determined by rhythmic changes in expression of NLF-1, a chaperone protein that delivers the channel to the plasma membrane (Xie et al., 2013), and NLF-1 knockdown or NA mutations disrupted circadian behavior in flies (Flourakis et al., 2015). As discussed above, we also find that expression of Nalcn can activate RTN neurons in opposition to effects of $\mathrm{pH}$-sensitive background $\mathrm{K}^{+}$currents; in this case, a wake state-dependent influence of Nalcn on RTN neuron activity on respiratory chemosensitivity may reflect transmitterevoked modulation of the channel rather than (or in addition to) altered expression or membrane targeting.

\section{A role for Nalcn in control of breathing and the respiratory $\mathrm{CO}_{2}$ chemoreflex}

Mice with global genetic deletion of Nalcn die of respiratory failure within $24 \mathrm{~h}$ of birth (Lu et al., 2007). In addition, missense or nonsense mutations of Nalcn are associated with variable phenotypes that include respiratory distress in some patients (Al-Sayed et al., 2013; Köroğlu et al., 2013; Cochet-Bissuel et al., 2014; Chong et al., 2015; Gal et al., 2016). The different phenotypes likely reflect the broad distribution of the channel in the CNS (Lee et al., 1999; Lu et al., 2007), and respiratory dysfunction could be due to loss of the depolarizing leak $\mathrm{Na}^{+}$current in any number of cell groups within the respiratory control system (Feldman et al., 2013; Smith et al., 2013). Nonetheless, our experiments reveal that depletion of Nalcn selectively in RTN neurons disrupts their activation by $\mathrm{CO}_{2}$ and blunts the associated ventilatory stimulation. This study therefore presents a cell-specific role for mammalian Nalcn in a defined physiological function and an approach for specific and effective Nalcn knockdown that can be applied to other cell groups where the channel is highly expressed.

Note added in proof: While this manuscript was under consideration, a description of Nalcn contributions to firing and glyoclytic sensitivity of substantia nigra pars reticulata neurons became available (eLife 2016;5: e15271).

\section{References}

Abbott SB, Stornetta RL, Fortuna MG, Depuy SD, West GH, Harris TE, Guyenet PG (2009) Photostimulation of retrotrapezoid nucleus phox 2 b-expressing neurons in vivo produces long-lasting activation of breathing in rats. J Neurosci 29:5806-5819. CrossRef Medline

Al-Sayed MD, Al-Zaidan H, Albakheet A, Hakami H, Kenana R, Al-Yafee Y, Al-Dosary M, Qari A, Al-Sheddi T, Al-Muheiza M, Al-Qubbaj W, Lakmache Y, Al-Hindi H, Ghaziuddin M, Colak D, Kaya N (2013) Mutations in NALCN cause an autosomal-recessive syndrome with severe hypotonia, speech impairment, and cognitive delay. Am J Hum Genet 93: 721-726. CrossRef Medline

Amiel J, Laudier B, Attié-Bitach T, Trang H, de Pontual L, Gener B, Trochet D, Etchevers H, Ray P, Simonneau M, Vekemans M, Munnich A, Gaultier C, Lyonnet S (2003) Polyalanine expansion and frameshift mutations of the paired-like homeobox gene PHOX2B in congenital central hypoventilation syndrome. Nat Genet 33:459-461. CrossRef Medline

Basting TM, Burke PG, Kanbar R, Viar KE, Stornetta DS, Stornetta RL, Guyenet PG (2015) Hypoxia silences retrotrapezoid nucleus respiratory chemoreceptors via alkalosis. J Neurosci 35:527-543. CrossRef Medline

Bean BP (2007) The action potential in mammalian central neurons. Nat Rev Neurosci 8:451-465. CrossRef Medline

Berger SM, Pesold B, Reber S, Schönig K, Berger AJ, Weidenfeld I, Miao J, Berger MR, Gruss OJ, Bartsch D (2010) Quantitative analysis of condi- 
tional gene inactivation using rationally designed, tetracycline-controlled miRNAs. Nucleic Acids Res 38:e168. CrossRef Medline

Burke PG, Kanbar R, Basting TM, Hodges WM, Viar KE, Stornetta RL, Guyenet PG (2015) State-dependent control of breathing by the retrotrapezoid nucleus. J Physiol 593:2909-2926. CrossRef Medline

Chong JX, McMillin MJ, Shively KM, Beck AE, Marvin CT, Armenteros JR, Buckingham KJ, Nkinsi NT, Boyle EA, Berry MN, Bocian M, Foulds N, Uzielli ML, Haldeman-Englert C, Hennekam RC, Kaplan P, Kline AD, Mercer CL, Nowaczyk MJ, Klein Wassink-Ruiter JS, et al. (2015) De novo mutations in NALCN cause a syndrome characterized by congenital contractures of the limbs and face, hypotonia, and developmental delay. Am J Hum Genet 96:462-473. CrossRef Medline

Cochet-Bissuel M, Lory P, Monteil A (2014) The sodium leak channel, NALCN, in health and disease. Front Cell Neurosci 8:132. CrossRef Medline

Dubreuil V, Ramanantsoa N, Trochet D, Vaubourg V, Amiel J, Gallego J, Brunet JF, Goridis C (2008) A human mutation in Phox 2b causes lack of $\mathrm{CO}_{2}$ chemosensitivity, fatal central apnea, and specific loss of parafacial neurons. Proc Natl Acad Sci U S A 105:1067-1072. CrossRef Medline

Eggermann E, Bayer L, Serafin M, Saint-Mleux B, Bernheim L, Machard D, Jones BE, Mühlethaler M (2003) The wake-promoting hypocretinorexin neurons are in an intrinsic state of membrane depolarization. J Neurosci 23:1557-1562. Medline

Feldman JL, Del Negro CA, Gray PA (2013) Understanding the rhythm of breathing: so near, yet so far. Annu Rev Physiol 75:423-452. CrossRef Medline

Flourakis M, Kula-Eversole E, Hutchison AL, Han TH, Aranda K, Moose DL, White KP, Dinner AR, Lear BC, Ren D, Diekman CO, Raman IM, Allada R (2015) A conserved bicycle model for circadian clock control of membrane excitability. Cell 162:836-848. CrossRef Medline

Gal M, Magen D, Zahran Y, Ravid S, Eran A, Khayat M, Gafni C, Levanon EY, Mandel H (2016) A novel homozygous splice site mutation in NALCN identified in siblings with cachexia, strabismus, severe intellectual disability, epilepsy and abnormal respiratory rhythm. Eur J Med Genet 59: 204-209. CrossRef Medline

Gourine AV, Kasymov V, Marina N, Tang F, Figueiredo MF, Lane S, Teschemacher AG, Spyer KM, Deisseroth K, Kasparov S (2010) Astrocytes control breathing through pH-dependent release of ATP. Science 329: 571-575. CrossRef Medline

Guyenet PG, Bayliss DA (2015) Neural control of breathing and $\mathrm{CO}_{2}$ homeostasis. Neuron 87:946-961. CrossRef Medline

Hawkins VE, Hawryluk JM, Takakura AC, Tzingounis AV, Moreira TS, Mulkey DK (2015) HCN channels contribute to serotonergic modulation of ventral surface chemosensitive neurons and respiratory activity. J Neurophysiol 113:1195-1205. CrossRef Medline

Hawryluk JM, Moreira TS, Takakura AC, Wenker IC, Tzingounis AV, Mulkey DK (2012) KCNQ channels determine serotonergic modulation of ventral surface chemoreceptors and respiratory drive. J Neurosci 32:16943-16952. CrossRef Medline

Hodges MR, Tattersall GJ, Harris MB, McEvoy SD, Richerson DN, Deneris ES, Johnson RL, Chen ZF, Richerson GB (2008) Defects in breathing and thermoregulation in mice with near-complete absence of central serotonin neurons. J Neurosci 28:2495-2505. CrossRef Medline

HökfeltT, Ljungdahl A, Steinbusch H, Verhofstad A, Nilsson G, Brodin E, Pernow B, Goldstein M (1978) Immunohistochemical evidence of substance P-like immunoreactivity in some 5-hydroxytryptamine-containing neurons in the rat central nervous system. Neuroscience 3:517-538. CrossRef Medline

Hwang DY, Carlezon WA Jr, Isacson O, Kim KS (2001) A high-efficiency synthetic promoter that drives transgene expression selectively in noradrenergic neurons. Hum Gene Ther 12:1731-1740. CrossRef Medline

Jackson AC, Yao GL, Bean BP (2004) Mechanism of spontaneous firing in dorsomedial suprachiasmatic nucleus neurons. J Neurosci 24:7985-7998. CrossRef Medline

Jacobs BL, Martín-Cora FJ, Fornal CA (2002) Activity of medullary serotonergic neurons in freely moving animals. Brain Res Brain Res Rev 40: 45-52. CrossRef Medline

Khaliq ZM, Bean BP (2010) Pacemaking in dopaminergic ventral tegmental area neurons: depolarizing drive from background and voltagedependent sodium conductances. J Neurosci 30:7401-7413. CrossRef Medline

Koizumi H, Smith JC (2008) Persistent $\mathrm{Na}^{+}$and $\mathrm{K}^{+}$-dominated leak cur- rents contribute to respiratory rhythm generation in the pre-Botzinger complex in vitro. J Neurosci 28:1773-1785. CrossRef Medline

Köroğlu C, Seven M, Tolun A (2013) Recessive truncating NALCN mutation in infantile neuroaxonal dystrophy with facial dysmorphism. J Med Genet 50:515-520. CrossRef Medline

Krieger J (2000) Respiratory physiology: breathing in normal subjects. Philadelphia: Saunders.

Kumar NN, Bowman BR, Goodchild AK (2012) Combined in situ hybridization and immunohistochemistry in rat brain tissue using digoxigeninlabeled riboprobes. In: Visualization techniques (Badoer E, ed), pp 31-52: Totowa, NJ: Humana.

Kumar NN, Velic A, Soliz J, Shi Y, Li K, Wang S, Weaver JL, Sen J, Abbott SB, Lazarenko RM, Ludwig MG, Perez-Reyes E, Mohebbi N, Bettoni C, Gassmann M, Suply T, Seuwen K, Guyenet PG, Wagner CA, Bayliss DA (2015) PHYSIOLOGY: regulation of breathing by $\mathrm{CO}(2)$ requires the proton-activated receptor GPR4 in retrotrapezoid nucleus neurons. Science 348:1255-1260. CrossRef Medline

Lazarenko RM, Milner TA, Depuy SD, Stornetta RL, West GH, Kievits JA, Bayliss DA, Guyenet PG (2009) Acid sensitivity and ultrastructure of the retrotrapezoid nucleus in Phox2b-EGFP transgenic mice. J Comp Neurol 517:69-86. CrossRef Medline

Lazarenko RM, Fortuna MG, Shi Y, Mulkey DK, Takakura AC, Moreira TS, Guyenet PG, Bayliss DA (2010) Anesthetic activation of central respiratory chemoreceptor neurons involves inhibition of a THIK-1-like background $\mathrm{K}(+)$ current. J Neurosci 30:9324-9334. CrossRef Medline

Lee JH, Cribbs LL, Perez-Reyes E (1999) Cloning of a novel four repeat protein related to voltage-gated sodium and calcium channels. FEBS Lett 445:231-236. CrossRef Medline

Lim CS, Hoang ET, Viar KE, Stornetta RL, Scott MM, Zhu JJ (2014) Pharmacological rescue of Ras signaling, GluA1-dependent synaptic plasticity, and learning deficits in a fragile X model. Genes Dev 28:273-289. CrossRef Medline

Liss B (2002) Improved quantitative real-time RT-PCR for expression profiling of individual cells. Nucleic Acids Res 30:e89. CrossRef Medline

Loria CJ, Stevens AM, Crummy E, Casadesus G, Jacono FJ, Dick TE, Siegel RE (2013) Respiratory and behavioral dysfunction following loss of the GABAA receptor alpha4 subunit. Brain Behav 3:104-113. CrossRef Medline

Lu B, Su Y, Das S, Liu J, Xia J, Ren D (2007) The neuronal channel NALCN contributes resting sodium permeability and is required for normal respiratory rhythm. Cell 129:371-383. CrossRef Medline

Lu B, Su Y, Das S, Wang H, Wang Y, Liu J, Ren D (2009) Peptide neurotransmitters activate a cation channel complex of NALCN and UNC-80. Nature 457:741-744. CrossRef Medline

Marina N, Abdala AP, Trapp S, Li A, Nattie EE, Hewinson J, Smith JC, Paton JF, Gourine AV (2010) Essential role of Phox2b-expressing ventrolateral brainstem neurons in the chemosensory control of inspiration and expiration. J Neurosci 30:12466-12473. CrossRef Medline

McBride JL, Boudreau RL, Harper SQ, Staber PD, Monteys AM, Martins I, Gilmore BL, Burstein H, Peluso RW, Polisky B, Carter BJ, Davidson BL (2008) Artificial miRNAs mitigate shRNA-mediated toxicity in the brain: implications for the therapeutic development of RNAi. Proc Natl Acad Sci U S A 105:5868-5873. CrossRef Medline

Mulkey DK, Stornetta RL, Weston MC, Simmons JR, Parker A, Bayliss DA, Guyenet PG (2004) Respiratory control by ventral surface chemoreceptor neurons in rats. Nat Neurosci 7:1360-1369. CrossRef Medline

Mulkey DK, Rosin DL, West G, Takakura AC, Moreira TS, Bayliss DA, Guyenet PG (2007) Serotonergic neurons activate chemosensitive retrotrapezoid nucleus neurons by a $\mathrm{pH}$-independent mechanism. J Neurosci 27: 14128-14138. CrossRef Medline

Nattie EE, Li A (2002) Substance P-saporin lesion of neurons with NK1 receptors in one chemoreceptor site in rats decreases ventilation and chemosensitivity. J Physiol 544:603-616. CrossRef Medline

Paxinos GF, Franklin KBJ (2001) The mouse brain in stereotaxic coordinates, Ed 2. San Diego: Elsevier.

Perkins KL (2006) Cell-attached voltage-clamp and current-clamp recording and stimulation techniques in brain slices. J Neurosci Methods 154: 1-18. CrossRef Medline

Pfaffl MW (2001) A new mathematical model for relative quantification in real-time RT-PCR. Nucleic Acids Res 29:e45. CrossRef Medline

Qin Y, Zhu Y, Baumgart JP, Stornetta RL, Seidenman K, Mack V, van Aelst L, 
Zhu JJ (2005) State-dependent Ras signaling and AMPA receptor trafficking. Genes Dev 19:2000-2015. CrossRef Medline

Raman IM, Bean BP (1997) Resurgent sodium current and action potential formation in dissociated cerebellar Purkinje neurons. J Neurosci 17: 4517-4526. Medline

Raman IM, Gustafson AE, Padgett D (2000) Ionic currents and spontaneous firing in neurons isolated from the cerebellar nuclei. J Neurosci 20 : 9004-9016. Medline

Ramanantsoa N, Hirsch MR, Thoby-Brisson M, Dubreuil V, Bouvier J, Ruffault PL, Matrot B, Fortin G, Brunet JF, Gallego J, Goridis C (2011) Breathing without $\mathrm{CO}(2)$ chemosensitivity in conditional Phox $2 \mathrm{~b}$ mutants. J Neurosci 31:12880-12888. CrossRef Medline

Ren D (2011) Sodium leak channels in neuronal excitability and rhythmic behaviors. Neuron 72:899-911. CrossRef Medline

Sato M, Severinghaus JW, Basbaum AI (1992) Medullary $\mathrm{CO}_{2}$ chemoreceptor neuron identification by c-fos immunocytochemistry. J Appl Physiol 73:96-100. Medline

Smith JC, Abdala AP, Borgmann A, Rybak IA, Paton JF (2013) Brainstem respiratory networks: building blocks and microcircuits. Trends Neurosci 36:152-162. CrossRef Medline

Swayne LA, Mezghrani A, Lory P, Nargeot J, Monteil A (2010) The NALCN ion channel is a new actor in pancreatic beta-cell physiology. Islets 2: 54-56. CrossRef Medline

Taddese A, Bean BP (2002) Subthreshold sodium current from rapidly in- activating sodium channels drives spontaneous firing of tuberomammillary neurons. Neuron 33:587-600. CrossRef Medline

Takakura AC, Moreira TS, Stornetta RL, West GH, Gwilt JM, Guyenet PG (2008) Selective lesion of retrotrapezoid Phox2b-expressing neurons raises the apnoeic threshold in rats. J Physiol 586:2975-2991. CrossRef Medline

Veasey SC, Fornal CA, Metzler CW, Jacobs BL (1995) Response of serotonergic caudal raphe neurons in relation to specific motor activities in freely moving cats. J Neurosci 15:5346-5359. Medline

Wang S, Shi Y, Shu S, Guyenet PG, Bayliss DA (2013a) Phox2b-expressing retrotrapezoid neurons are intrinsically responsive to $\mathrm{H}^{+}$and $\mathrm{CO}_{2}$. J Neurosci 33:7756-7761. CrossRef Medline

Wang S, Benamer N, Zanella S, Kumar NN, Shi Y, Bévengut M, Penton D, Guyenet PG, Lesage F, Gestreau C, Barhanin J, Bayliss DA (2013b) TASK-2 channels contribute to $\mathrm{pH}$ sensitivity of retrotrapezoid nucleus chemoreceptor neurons. J Neurosci 33:16033-16044. CrossRef Medline

Weese-Mayer DE, Berry-Kravis EM, Ceccherini I, Keens TG, Loghmanee DA, Trang H (2010) An official ATS clinical policy statement. Congenital central hypoventilation syndrome: genetic basis, diagnosis, and management. Am J Respir Crit Care Med 181:626-644. CrossRef Medline

Xie L, Gao S, Alcaire SM, Aoyagi K, Wang Y, Griffin JK, Stagljar I, Nagamatsu S, Zhen M (2013) NLF-1 delivers a sodium leak channel to regulate neuronal excitability and modulate rhythmic locomotion. Neuron 77 : 1069-1082. CrossRef Medline 